\title{
Potential Therapeutic Applications of Bee Venom on Skin Disease and Its Mechanisms: A Literature Review
}

\author{
Haejoong Kim ${ }^{1}$, Soo-Yeon Park ${ }^{2, *}$ and Gihyun Lee ${ }^{1, *[C}$ \\ 1 College of Korean Medicine, Dongshin University, Naju-si, Jeollanam-do 58245, Korea \\ 2 Department of Ophthalmology, Otolaryngology \& Dermatology, College of Korean Medicine, \\ Dongshin University, Naju-si, Jeollanam-do 58245, Korea \\ * Correspondence: swallow92@dsu.ac.kr (S.-Y.P.); glee@khu.ac.kr (G.L.)
}

Received: 3 June 2019; Accepted: 25 June 2019; Published: 27 June 2019

\begin{abstract}
Skin is larger than any other organ in humans. Like other organs, various bacterial, viral, and inflammatory diseases, as well as cancer, affect the skin. Skin diseases like acne, atopic dermatitis, and psoriasis often reduce the quality of life seriously. Therefore, effective treatment of skin disorders is important despite them not being life-threatening. Conventional medicines for skin diseases include corticosteroids and antimicrobial drugs, which are effective in treating many inflammatory and infectious skin diseases; however, there are growing concerns about the side effects of these therapies, especially during long-term use in relapsing or intractable diseases. Hence, many researchers are trying to develop alternative treatments, especially from natural sources, to resolve these limitations. Bee venom (BV) is an attractive candidate because many experimental and clinical reports show that BV exhibits anti-inflammatory, anti-apoptotic, anti-fibrotic, antibacterial, antiviral, antifungal, and anticancer effects. Here, we review the therapeutic applications of BV in skin diseases, including acne, alopecia, atopic dermatitis, melanoma, morphea, photoaging, psoriasis, wounds, wrinkles, and vitiligo. Moreover, we explore the therapeutic mechanisms of BV in the treatment of skin diseases and killing effects of BV on skin disease-causing pathogens, including bacteria, fungi and viruses.
\end{abstract}

Keywords: bee venom; alternative treatment; skin; cutaneous disease; mechanism

Key Contribution: This review summarizes the therapeutic applications of BV in skin diseases, including acne, alopecia, atopic dermatitis, melanoma, morphea, photoaging, psoriasis, wounds, wrinkles, and vitiligo. It also deals with the therapeutic mechanisms of BV in the treatment of skin diseases and killing effects of BV on skin disease-causing pathogens, including bacteria, fungi and viruses.

\section{Introduction}

Bee venom (BV), produced by honeybees (Apis mellifera), is one of the most well-known natural toxins. BV is a very diverse set of chemicals. It includes peptides such as melittin, apamine, adolapin, and MCD peptide, enzymes like phospholipase A2 (PLA2), hyaluronidase, acid phosphomonoesterase, and lysophosphofolipase, and it also contains various amines such as histamine, dopamine, and norepinephrine [1].

BV has long been used as a therapeutic substance. It generally has been administrated in the form of piercing directly with bee sting, or injecting extracted and purified BV with a syringe. In oriental medicine, BV is also injected into specific acupoints related with a disorder [2,3]. BV has been broadly used for reducing pain and suppressing inflammation in musculoskeletal disorders, such as osteoarthritis, rheumatoid arthritis, and lumbar pain [2,4-6], and in recent years, its therapeutic effects in treating neurological diseases like chronic neuralgia, Parkinson's disease, and amyotrophic 
lateral sclerosis have been reported $[7,8]$. Another recent study also showed that BV has a therapeutic effect on periodontal disease [9]. Accumulated evidence shows that BV has anti-inflammatory, anti-apoptotic, antifibrotic, and anti-atherosclerotic properties which support these therapeutic applications [10]. In addition, a number of recent studies have demonstrated antibacterial, antiviral, antifungal, and anticancer effects of BV [1,11-17].

Many reviews have highlighted the therapeutic value of BV, but none have focused on the effect of BV on skin diseases. To the best of our knowledge, this is the first review that summarizes the potential therapeutic mechanisms and applications of BV in skin diseases. They are shown at ahead of discussion in order of clinical study, in vivo study, and in vitro study (Tables 1-3). To date, skin diseases where therapeutic application of BV has been studied include acne, alopecia, atopic dermatitis, melanoma, morphea, photoaging, psoriasis, wound, wrinkle, and vitiligo (Figure 1). The purpose of this review is to provide the present knowledge from a various experimental and clinical reports and to help researchers design a follow-up study from previous studies and diseases that are yet to be studied.

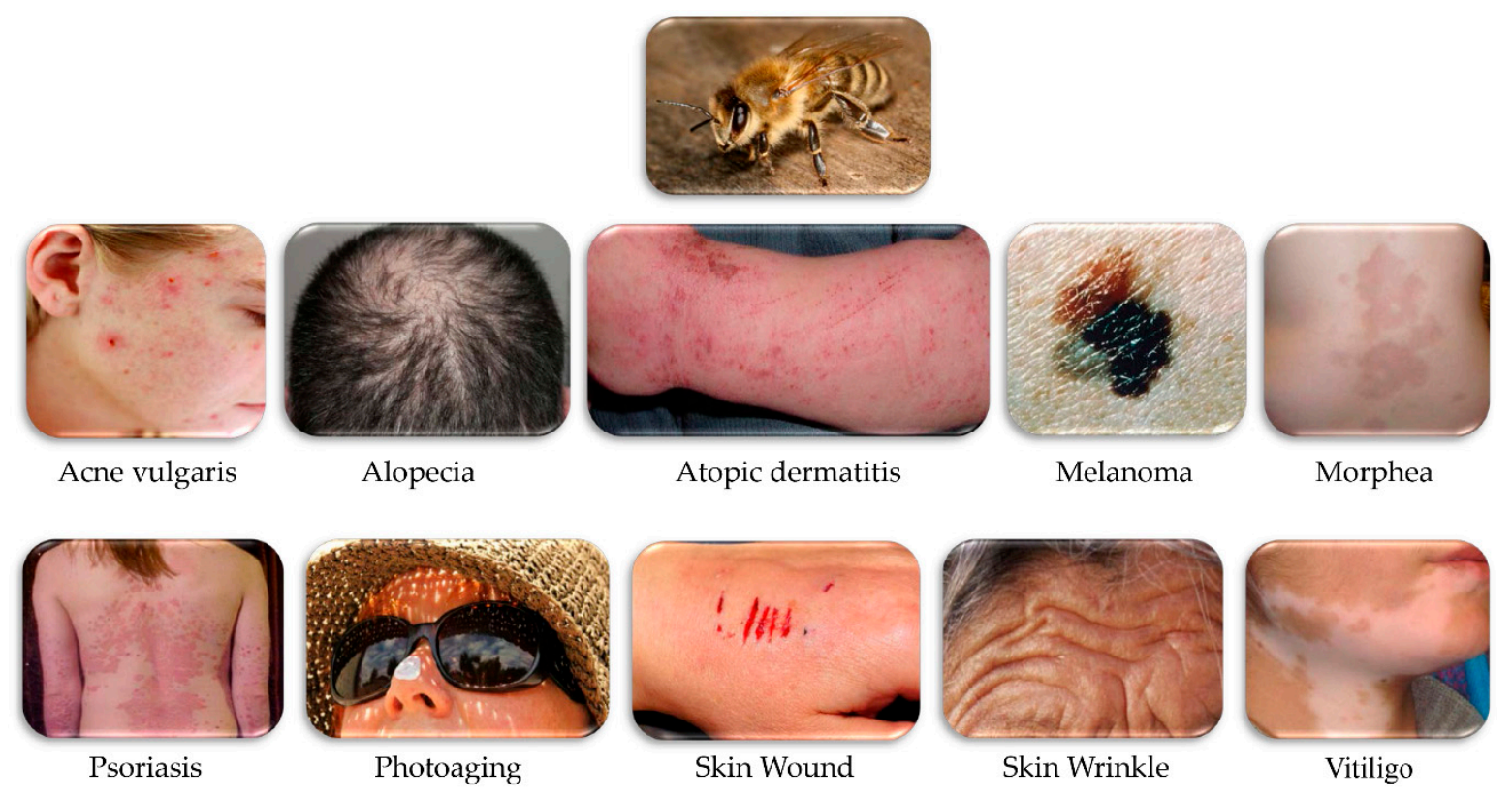

Figure 1. Skin diseases where the therapeutic application of bee venom (BV) has been studied.

\section{Therapeutic Effects of BV in Skin Diseases}

\subsection{Acne}

Acne, marked by the development of papules, pustules, and nodules, is an inflammatory disorder which occurred on the sebaceous unit. Acne is generally observed on the skin of the face, breast, and back. Pathological features of acne include increased sebum secretion, inflammation, keratinization of sebaceous ducts, and bacterial colonization of sebaceous ducts [18,19]. Antibiotics, one of the various treatment options for acne, have been utilized to suppress inflammation by killing the causative bacteria [20]. However, frequent use of antibiotics poses the risk of side effects, like the appearance of resistant bacterial strains [21,22]. Therefore, there is a growing interest in acne treatments which have a higher therapeutic effect and fewer side effects [22,23]. There are currently many studies demonstrating that $\mathrm{BV}$ might be effective for acne vulgaris.

\subsubsection{Clinical Studies}

In a randomized double-blind control trial of Han et al., to examine the therapeutic effects of BV on acne, a total of 12 subjects received either skincare products containing BV or products without BV for 2 weeks. The BV group showed a notable advancement in the grading levels based upon the 
count of inflammatory and non-inflammatory lesions compared to the control. In the study, patients applying cosmetics containing BV showed a reduction by $57.5 \%$ in ATP levels, measured to assess a decrease in the count of skin microbes. These results show that cosmetics containing BV may be good candidates for therapeutic agents for acne [24].

In a prospective, non-comparative study of Han et al., 30 subjects with mild to moderate acne were recruited and managed with cosmetics containing BV twice daily for 6 weeks. All the volunteers showed significant improvement in the average visual acne grade compared to the start. The mean extent of improvement in acne grade after 6 -weeks was $52.3 \%$, and $77 \%$ of the subjects showed advancement in terms of whiteheads and blackheads, papules, pustules, and nodules 6 weeks later compared with the start of the treatment. There was no skin trouble noticed during the progress of the study. These results demonstrated that cosmetics containing BV showed a marked therapeutic effect on acne [25].

\subsubsection{In Vivo Studies}

Propionibacterium acnes (P. acnes) is the main factor that induces inflammation in acne [26]. As a member of normal bacterial flora, $P$. acnes coexists in our skin, but its excessive proliferation plays a key role in the development of inflammatory acne. It contributes to the inflammatory response of acne by stimulating the production of inflammatory cytokines like IL-8, IL-1 $\beta$ and TNF- $\alpha$ from keratinocytes, sebocytes, and inflammatory cells [27].

An et al. intradermally injected P.acnes into the ears of mice, and then BV was applied to the right ear only to examine the therapeutic effects of BV on inflammatory skin disease induced by P. acnes. BV treatment significantly decreased the inflammatory cells infiltration, and the expression of TNF- $\alpha$ and IL-1 $\beta$ decreased significantly in the BV-treated ear as compared to the untreated ear. The expression of CD14 and TLR2 was also significantly inhibited by BV treatment in P. acnes-treated tissue. In addition, the transcriptional activity of NF- $\mathrm{kB}$ and AP-1 was noticeably inhibited after BV injection. These results indicate that BV may be beneficial in treating acne [28].

Melitin, the main component of $\mathrm{BV}$, is cationic and is also a toxic peptide that causes hemolysis [29]. Interestingly, recent in vitro and in vivo studies have shown that these cytotoxic melittins can be used to treat inflammatory diseases by reducing excessive immune responses [30]. Lee et al. investigated the therapeutic efficacy of melitin as an alternative treatment for inflammatory skin diseases caused by P. acnes. In this study, melittin significantly decreased the swelling and granulomatous inflammation response, which were induced by intradermal injection of $P$. acnes, in the ear when compared to the ear that only P. acnes was injected into. The thickness of the ear injected with melittin showed a 1.3-fold decrease in comparison to the ears that only P. acnes was injected into. Moreover, melittin evidently downregulated the expression of TNF- $\alpha$ and IL-1 $\beta$, which further led to remarkable suppression of CD14 and TLR2 expression. These outcomes indicate that the application of melittin has potential for the treatment of P. acnes-induced inflammatory skin disorder [31].

\subsubsection{In Vitro Studies}

In vitro studies of Hari et al. using human keratinocytes and monocyte cells stimulated by heat-killed P. acne showed that BV reduced the production of IL-8, TNF- $\alpha$, and IFN- $\gamma$ in HaCaT and THP-1 cells. BV also suppressed TLR2 expression, which was induced by heat-killed P. acnes-induced, in HaCaT and THP-1 cells in a dose-dependent manner. The activation of TLR encourages the secretion of chemokines, pro-inflammatory cytokines, leukotrienes, and prostaglandins [32].

In the study of Han et al., BV decreased the production of IL- 8 and TNF- $\alpha$, which was caused by P. acnes, in THP- 1 cell in a similar manner. In this study, BV showed low cytotoxicity against human keratinocytes and monocyte below $10 \mu \mathrm{g} / \mathrm{mL}$ [33]. These results indicate that BV might alternate antibiotic treatment for acne.

Lee et al. tested melittin as a therapeutic agent in heat-killed P. acnes-treated keratinocytes. In this study, the injection of melittin considerably reduced the expression of diverse inflammatory cytokines, 
such as TNF- $\alpha$, IL-8, IL-1 $\beta$, and IFN- $\gamma$. Melittin treatment suppressed the expression of TNF- $\alpha$ and IL-1 $\beta$ via regulating NF- $\mathrm{KB}$ and MAPK pathways in keratinocytes. In this study, melittin did not influence the cell viability of HaCaT cells during 8 hours of treatment. [31]

\subsection{Alopecia}

Hair is regarded as one of the most crucial parts of a person's look. Therefore, loss of hair could negatively affect self-worth and impair life quality. Genetic predisposition is the most common reason of hair loss, but stress is also believed to play a crucial role, specifically in the younger generation. Inflammation of the scalp is also associated with hair loss. According to a recent study, $74.1 \%$ of patients diagnosed with alopecia have inflammatory disorders, such as atopic and contact dermatitis. Mental illnesses account for $25.5 \%$ of the cases [34].

\subsubsection{In Vivo Studies}

Park et al. investigated the preventive effect of BV on alopecia by application of BV or minoxidil (2\%) to the dorsal surface of mice for 19 days. Dexamethasone (DEX) was used to induce catagen in mice. In this study, BV promoted hair growth in mice by decreasing the levels of $5 \alpha$-reductase and increasing keratinocyte growth factor (KGF), which stimulates follicular proliferation [35]. 5 $\alpha$-reductase enzymatically catalyzed the conversion of testosterone into DHT that has a higher affinity against androgen receptors than testosterone, which led to stimulating hair loss by the expression of genes associated with hair follicle minimization [36]. Finasteride and dutasteride, which are currently used as hair loss treatment agents based on inhibiting $5 \alpha$-reductase, can cause severe side effects, including sexual dysfunction, depression, and gynecomastia, which generally lead to treatment discontinuation $[37,38]$. In this study, no edema, erythema, irritation, and cytotoxicity were observed after BV treatment. These results suggest that BV may be used as a hair growth-promoting agent [35].

\subsubsection{In Vitro Studies}

The length of hair relies on the duration of the anagen phase [39]. At any given time, hair, which is in anagen, catagen, and telogen phase, accounts for $90 \%, 1 \%$, and $9 \%$ respectively [40]. In vitro studies using DEX-stimulated human dermal papilla cells (hDPCs) showed that BV elevates the proliferation of hDPCs and upregulates growth factors, including FGF7, FGF2, VEGF, and IGF-1 that keep hair in the anagen stage, and hence encourage hair growth in hDPCs [35]. BV presents the potential to be used as a treatment for hair loss, since it can stimulate hair growth by increasing hair growth factors and suppressing the progression to catagen phase.

\subsection{Atopic Dermatitis (AD)}

Atopic dermatitis (AD) is a chronic and relapsing inflammatory skin disorder that is marked by a defective skin barrier, eczema, pruritus, dry skin, and an abnormal IgE-mediated allergic response to diverse external antigens [41].

The incidence of $\mathrm{AD}$ has increased considerably in recent years. About 1 to $3 \%$ of adults and a maximum of $20 \%$ of children have at some point suffered from AD [42]. Antihistamines, steroids, NSAIDs and immunosuppressants have been utilized to treat AD [43-45]. Regrettably, these medications have serious adverse effects, like nephrotoxicity and neurotoxicity [43,46]. Thus, natural substances have emerged as alternative therapeutic agents for immune disorders, such as AD because they are considered to have strong immunomodulatory effects and fewer side effects [47]. Emerging evidence indicates that $\mathrm{BV}$ alleviates $\mathrm{AD}$ via its anti-inflammatory mechanisms in clinical trials in vivo and in vitro studies. 


\subsubsection{Clinical Studies}

The disease management for AD is on the basis of hydrating the skin and restoring the collapsed epidermal barrier. Regular use of suitable moisturizer is an important part of therapy for AD because xerosis and barrier malfunction are the major symptoms of $\mathrm{AD}$ [48]. In the study of You et al., 136 subjects with diagnosed $\mathrm{AD}$ were randomly distributed in different groups and were made to apply either a moisturizer containing BV and silk protein or a moisturizer just without BV for 4 weeks. Subjects who applied emollient with BV showed significantly lower Eczema Area and Severity Index (EASI) and visual analogue scale (VAS) value compared to patients who applied emollient without BV. There were no outstanding differences in the incidence of side effects induced by BV on patients' skin [49].

\subsubsection{In Vivo Studies}

Gu et al. investigated the advancement of AD-like lesions caused by ovalbumin (OVA), which are major egg white proteins, and the mechanism of therapeutic action of BV simultaneously. Histological analysis of dorsal skin thickness indicated that intraperitoneal administration of BV reduced the symptoms of AD. BV inhibited inflammatory cytokines by decreasing IgE secretion, TNF- $\alpha$, and thymic stromal lymphopoetin (TSLP). It also suppressed the infiltration of eosinophils and mast cells into the lesion. These outcomes indicate BV has a possibility to be developed as an alternative for AD treatment due to the effective inhibition of allergic skin inflammation in AD [50].

Kim et al. noted the relationship between hyperactivity of the complement system and the inflammatory response of AD. In a mouse model in which atopic lesions were induced by 1-chloro-2,4-dinitrobenzene (DNCB), subcutaneous injection of BV almost completely resolved the symptoms of AD. In this study, BV significantly increased the secretion of CD55, a complement formation inhibitor, from THP-1 cells, resulting in a significant reduction in serum C3C and MAC levels, which were evaluated as an indicator of complement system activation. These results suggest that BV may be able to manage AD by inducing CD55 production that inhibits activity of complement system [51].

Itching, a sensation that causes the desire to scratch, is the most outstanding symptom of AD, and continuous scratching further worsens AD symptoms [52]. In the compound 48/80-induced mouse skin scratching model used in study of Kim et al, intraperitoneal administration of BV mitigated scratching behavior in mice. This anti-scratching effect correlated with vascular permeability effects of BV. In this study, BV also significantly suppressed mast cell degranulation and the production of pro-inflammatory cytokines including TNF- $\alpha$ and IL-1 $\beta$ by downregulating the activation of the NF-KB pathway in compound 48/80-treated epidermal tissues. These outcome indicate that BV might be used to ameliorate compound 48/80-induced AD symptoms [47]. In traditional Oriental medicine, BV acupuncture (BVA), which involves injecting BV into acupoints, has been utilized to treat various chronic inflammatory disorder of humans. In a mouse model of thrombotic micro-angiopathy (TMA)-induced AD used in study of Sur et al., BVA treatment at BL40 acupoint in the ear significantly inhibited the expression of both Th1 and Th2 cytokines in lymph nodes and ear skin. The severity of ear skin infection symptoms as AD-like symptoms, including thickness, inflammation, and increased lymph node weight, were considerably soothed by BVA treatment. The proliferation and infiltration of T cells and the synthesis of IL-4 and IgE, which are typical Th2 allergic responses, were also suppressed by BVA treatment. Interestingly, BVA at BL40 acupoint showed a more pronounced inhibitory effect compared to the non-acupoint placed on the base of the tail. These outcomes suggest that injecting BV at specific acupoints successfully relieves AD-like lesions by suppressing allergic and inflammatory responses in a mouse with TMA-induced AD. [53]

Several studies have investigated the pharmacological effects of melittin, the main component of BV. In the study of An et al. using mouse with DNCB-induced AD, topical application of melittin significantly alleviated AD-like symptoms, such as dorsal skin thickness by decreasing the number of mast cell infiltration, CD4+ T cells and the serum level of IgE, IL-4, IFN- $\gamma$, and TSLP. In addition, 
whole BV and melittin restored the abnormal differentiation of epidermis by recovering the expression of filaggrin. These results indicate that melittin could be a suitable agent for the therapy of AD [54].

In the study of Kim et al., intraperitoneally-injected BV also improved OVA-induced AD-like symptoms, such as an increase in skin thickness, edema, erythema, and excoriation in mice by inhibiting mast cell infiltration, by decreasing filaggrin levels, and secretion of AD-related inflammatory chemokines and cytokines, including CD14, CD11b, IL-1 $\beta$, TNF- $\alpha$, TSLP, and an excessive IgE response. Taken together, these results confirm that melittin has therapeutic effects on AD-like symptoms. [55]

PLA2, another major component of BV, plays a central role in various cellular responses, such as signal transduction, and the regulation of inflammatory and immune responses and phospholipid metabolism [56,57]. In Dermatophagoides farinae extract (DFE)-induced AD mouse model used in the study of Jung et al., topical application of PLA2 significantly decreased the serum IgE, Th1, and Th2 cytokines. AD-induced histological changes and mast cells infiltration were alleviated by PLA2 application. Meanwhile, the depletion of regulatory T cells eliminated the anti-atopic effects of PLA2, which suggests that anti-atopic effects of PLA2 rely on the functions of regulatory T cells. Overall, the results demonstrated that topical application of PLA2 might ameliorate atopic skin inflammation [58].

\subsubsection{In Vitro Studies}

The in-vitro study of An et al. using TNF- $\alpha /$ IFN- $\gamma$-treated human keratinocytes, melittin suppressed the production of chemokines, including CCL22 and CCL17, and pro-inflammatory cytokines such as IL-6, IL-1 $\beta$, and IFN- $\gamma$ by inhibiting the activation of NF-kB, STAT1, and STAT3 pathways. Modulating AD-associated cytokines and chemokines may therefore, offer therapeutic efficacy in patients with AD [54].

Filaggrin plays an important role in epidermal barrier function. The activation of STAT3 downregulates filaggrin and Th2-induced cytokines, including IL-4 and IL-13, which are known as activators of STAT3 signaling [59].

Kim et al. investigated anti-atopic effect of melittin using IL-4 and IL-13-stimulated human keratinocytes. In the study, melittin prevented filaggrin deficiency caused by IL-4/IL-13 and activation of STAT3 in keratinocytes. The report proposes that melittin may have a beneficial effect on the skin barrier function via inhibiting filaggrin deficiency by a reduction of IL-4, IL-13, pSTAT3, and TSLP expression [55].

\subsection{Melanoma}

Melanoma is a skin cancer which begins in melanocytes, which are cell types generally found in skin, eye and the bowel. The treatment for melanoma involves surgical removal, and adjuvant immuno-, chemo- and radiation therapy, which mainly destroy cancer cells by triggering apoptotic pathways [60].

\subsubsection{In Vivo Studies}

Soman et al. investigated the anticancer effect of melittin on B16F10 mouse melanoma [61]. Melittin is a cytolytic peptide that inserts itself into lipid bilayer membranes followed by oligomerization to make pores on membrane [62]. Although this action can be used to destroy harmful cells, the nonspecific cytotoxicity, genotoxicity and hemolytic action of melittin have restricted its therapeutic usage [30]. To overcome this limitation, investigators used perfluorocarbon nanoparticles, synthetic nanoscale vehicles, which can deliver melittin to both, targeted tumors and premalignant lesions. After intravenous injection of melittin-loaded nanoparticles, tumor weight decreased significantly ( $\sim 87 \%$ reduction). Melittin loaded on targeted nanoparticles induced cancer cell apoptosis via liberation of cytochrome $\mathrm{c}$ from mitochondria. In addition, histological analysis revealed a reduction in the number of proliferating cells, blood vessels and significant areas of necrosis. There were no apparent toxic effects in terms of changes in organ weight or serum chemical profile, and the levels of liver 
enzyme aspartate aminotransferase were significantly lower in the melittin group than the normal control [61].

\subsubsection{In Vitro Studies}

BV caused the shift of intracellular $\mathrm{Ca}^{2+}$ concentrations in human melanoma A2058 cells. Changes in intracellular $\mathrm{Ca}^{2+}$ concentration generated reactive oxygen species (ROS) and collapsed mitochondrial membrane potential. As a result, apoptosis-inducing factor (AIF) and endonuclease G (EndoG) were noted to be translocated from mitochondria into the nucleus to carry out apoptosis. The inactivation of AKT and the activation of JNK were also observed in this process. Taken together, these experimental results supply a probable description for the potential mechanisms of BV in melanoma [60].

\subsection{Morphea}

Morphea is known as a local scleroderma and is a unique inflammatory disease that affects the skin and subcutaneous tissue, resulting in excessive accumulation of collagen, which eventually leads to fibrosis. Morphea is sometimes itchy but painless. It typically begins in red or purple skin areas and becomes thick and white [63].

The exact pathogenesis of morphea is unknown and the causes of morphea are generally considered as immune activation and inflammatory reaction, vascular endocardial damage, fibrosis, and nodularization. At the present time, there is no recommended medicinal treatment for morphea. Hwang et al, showed the successful outcome of BVA treatment in circumscribed morphea in a patient with systemic sclerosis [64].

\section{Clinical Studies (Case Report)}

A 64-year-old female presented with circular white areas ( 1 and $3 \mathrm{~cm}$ in diameter) and a heavy itch in the right lateral iliac crest. Subcutaneously, BVA was administered two times for the 1st week and once a week for the following 3 weeks along the edge of the superficial circumscribed lesions. After the first treatment, scores of sleep disturbance and itchiness dropped from 6 to 2 and from 8 to 4 , respectively, on an 11 points numeric scale. At the 3rd visit, the patient reported that her itchiness had almost gone after two treatments, but it appeared intermittently. On the 5th visit, she reported that she did not feel the itchiness any more, and that she could sleep well. Her skin also improved. With a follow-up evaluation for 3 months, it was confirmed that her skin condition had improved drastically to resemble normal skin. Though there was a light itch at the site of BVA for around half a day following treatment, there were no other significant side effects during treatments. The result demonstrates the potential of BVA to be used as a local treatment for morphea [64].

\subsection{Photoaging}

Human skin is usually damaged by the exposure to ultraviolet (UV) ray of sunlight. Atmospheric ozone layer absorbs UVC, but both UVA and UVB arrive at the ground and have physiological effects [65]. In particular, UVB is regarded as one of the most hazardous environmental carcinogen because UVB irradiation can lead to the production of MMP-1 and MMP-3 in fibroblasts, inducing photoaging of the skin and progression of skin tumor [66].

\section{In Vitro Studies}

The in-vitro study of Han et al. using human dermal fibroblasts (HDF) irradiated by UVB, BV significantly decreased UV-induced MMP- 1 and MMP- 3 by $50-80 \%$ and $50-85 \%$, respectively, compared to controls. It also reduced the expression of MMP- 1 and MMP-3 mRNA. Moreover, BV promoted the recovery of the damage caused by UVB irradiation in HDF. One microgram/milliliter of BV exerted no remarkable effect on both cell viability and morphology. However, at the higher concentration of $10 \mu \mathrm{g} / \mathrm{mL}$, BV treatment declined cell viability up to $90 \%$ [67]. These results hint that 
BV might be utilized as a potential protective agent for inhibiting photoaging. It is considered that BV allergy is mainly due to its allergic components, such as PLA2. Hyunkyoung et al. investigated the efficacy of PLA2-free bee venom (PBV) in preventing photoaging by comparing it with original BV. In this study, both BV and PBV decreased the levels of MMP-1and MMP-13 in HaCaT cells and MMP-1, -2 and -3 in HDF cells, which are induced by UVB, and restored the cell damage and production of collagen. In addition, both BV and PBV downregulated UVB-induced activation of ERK1/2 and p38 in $\mathrm{HaCaT}$ and HDF cells. However, the difference between the two is that BV shows a cytotoxic effect, whereas PBV showed some advantages in preventing skin wrinkle formation without significant cytotoxicity [68].

Activities of MMPs induced by UVB caused the degradation of collagen, which led to the loss of elasticity of skin ultimately forming wrinkles [69]. These results suggest that the application of PBV appears to be an effective method in preventing skin wrinkles and protecting the skin from exposure to UVB.

\subsection{Psoriasis}

Psoriasis is a chronic inflammatory skin disorder marked by well-circumscribed erythematous plaques covered with silvery white scales. The exact pathology is unknown and is believed to be related to the production of inflammatory cytokines and kemokinesis following the activation of T-cells and several types of white blood cells that rule cellular immunity [70]. Unfortunately, current therapies can only suppress psoriasis but not cure it. Studies are being planned to evaluate the efficacy of BV as a new therapy in patients with psoriasis.

\section{Clinical Studies}

In the study of Hegazi et al., patients received an intradermal injection of BV. Before treatment and after 3 months of therapy, Psoriasis Area and Severity Index (PASI) score and serum IL-1 $\beta$ were measured to evaluate the outcome of treatment. Both PASI score and serum levels of IL- $1 \beta$ showed a significant decrease upon BV treatment [71]. These results were in accordance with a study which reported a decrease in levels of IL-1 $\beta$ from 289.5 to 29.2 in patients with guttate psoriasis followed by improvement in psoriasis after tonsillectomy [72].

In this study, intradermal injection of BV showed a superior outcome to oral or topical propolis, which were used as positive controls. Interestingly, unlike most treatments used in psoriasis, no systemic adverse effects were observed in all subjects. This indicates that BV might be a safe new treatment option and could be utilized in patients who have renal or liver dysfunctions [71].

Recalcitrant localized plaque psoriasis (RLPP) is characterized by lesions counting under $10 \%$ of body surface area which does not respond to any topical and systemic treatment [73]. Eltaher et al. used BV as alternative curative agent for RLPP, and their results exhibited full recovery in 23 out of $25(92 \%)$ of patients, whereas only one patient out of $25(4 \%)$ showed a recovery in symptoms in the placebo group. PGA score and TNF- $\alpha$ levels were remarkably decreased in patients treated with BV compared to the group with placebo. The activity of inflammatory cytokines, including TNF- $\alpha$, IL-6 and IL-1 $\beta$, is considered to take responsibility for the development of psoriasis [74]; hence, decreasing their levels might contribute to improvement of the disease. In this study, no adverse effects were observed excluding erythema, mild swelling and slight pain at the spot of BV injection and these troubles eventually got better. Psoriatic lesions did not relapse following 6 months of observation. These results suggested that BV could be safe and effective management for RLPP [75].

\subsection{Skin Wounds}

Wound healing is the result of a complex and dynamic course of tissue repair that includes various cellular and molecular events [76]. Wound healing is achieved through five interrelated phases; hemostasis and formation of clot, fibroplasias and neovascularization, granulation tissue formation, re-epithelialization, and creation of new ECM and tissue remodeling [77,78] 


\section{In Vivo Studies}

Han et al. examined the efficacy of BV on healing wound in mice. For research, full-thickness wounds were induced on the dorsal surface of mice, and mice were divided into BV control and Vaseline groups. All the treatments were applied on the gauze covering the wound. The expression of type 1 collagen showed an increase upon BV treatment compared to the other two groups. The speed of wound closure in the BV group was notably faster than in the other two groups. Histology also showed that BV induced remarkable progression of wound healing. In this study, BV reduced the level of fibronectin, TGF- $\beta 1$, and VEGF but elevated type 1 collagen. The results demonstrated that BV promoted wound healing by inhibiting cytokines related with fibrosis, which led to a reduction of wound size and an increase in propagation of epithelium in mice with full-thickness excision. These results suggest that the topical application of BV could be highly useful in decreasing the sizes of wounds [79].

In diabetic patients, skin wound healing disorders are often the cause of morbidity and mortality. Insufficient recruitment of macrophages and neutrophils at the wound and damage to neovascularization are responsible for impaired diabetic wound healing $[80,81]$.

Hozzein et al. examined the therapeutic effect and mechanism of BV on impaired wound healing caused by diabetes in a mouse model with type I diabetes mellitus. In this study, the rate of wound closure and recovery were increased in the BV-treated group in comparison to the control. Type I collagen showed significant restoration in diabetic mice treated with BV. In addition, the percentage of apoptotic macrophages decreased markedly in BV-treated groups compared to controls, which led to a significant increase of the phagocytic index. Furthermore, BV promoted angiogenesis via recovering Ang-1/Tie-2 signaling and increasing the expression of Nrf2, ERK, Akt/eNOS, and $\beta$-defensin-2, which shows a reduction in wound tissues in diabetic mice. These results indicate that BV could be applied as a new potential treatment for encouraging angiogenesis and repairing the impaired wound healing in diabetes [82].

\subsection{Skin Wrinkling}

Wrinkles are a change in appearance induced by ultraviolet rays, and the intrinsic aging process over a prolonged time. Both these factors induce collagen alteration, leading to skin aging. The desire to improve aging skin has led to the development of numerous cosmetics that slow down wrinkle formation. Currently, various ingredients have been added to theses cosmetics and BV is one of the added ingredients.

\section{Clinical Studies}

Han et al. assessed the beneficial effects of serum containing BV on facial wrinkles. The results of the application of BV-containing serum decreased average wrinkle depth, the total wrinkle area and count. Topical application of BV is considered to be safe for human skin since it showed no dermal irritation in animal researches [83]. Therefore, BV serum might be effective in improvement of skin wrinkles [84].

\subsection{Vitiligo}

Vitiligo is characterized by depigmentation of skin and hair. It is related to abnormal pigmentation resulting from melanocyte proliferation, melanogenesis, and migration or increases in dendricity $[85,86]$. Recently, phospholipase A2 of BV has been reported to stimulate melanocyte dendricity and pigmentation [86-88]. According to the authors, pigmentation which occurred around the injection sites and lasted a few months, had been observed after treatment with BV. One study investigated the effect of BV on the proliferation, melanogenesis, migration, dendricity, and signal transduction of human melanocytes. 
In Vitro Studies

In the study of Jeon et al., BV treatment elevated the melanocyte proliferation around twice compared to the control in 1 week. By BV treatment, the expression of MITF-M protein increased to the maximum levels on day 3 and slowly decreased till day 5. BV also activated PKA, ERK, and PI3K/Akt signaling. Moreover, BV treatment increased the ratio of cells with more than two dendrites by $23 \%$ in a time-dependent manner. The results also showed that BV treatment led to a two-fold increase in the number of migrated cells as compared to the controls. BV-induced melanocyte dendricity and melanocyte migration showed complete inhibition upon pre-treatment with PLA2 inhibitor and aristolochic acid, and this suggests that BV-induced melanocyte dendricity and melanocyte migration occur via the activation of PLA2.

The results of the in-vitro study indicated that BV has a positive effect on melanocyte proliferation, melanogenesis, dendricity, and migration. The result suggest that BV has a potential for treatment of vitiligo by repigmentation in skin [89].

\section{Inhibitory Effects of BV against Pathogenic Agent which is Related to Skin Disease}

\subsection{Bacteria}

\subsubsection{Propionibacterium Acnes, Clindamycin-Resistant P. acnes, Staphylococcus epidermidis, and} Streptococcus pyogenes

Propionibacterium acnes, Staphylococcus epidermidis, Streptococcus pyrogenes, and Staphylococcus aureus are microorganisms that originally exist on normal skin. During puberty, they proliferate rapidly and often contribute to the development of acne $[90,91]$. P. acnes infections mainly occur in the pilosebaceous unit. In contrast, aerobic organisms like S. epidermidis, S. pyrogenes, and S. aureus generally infect the sebaceous unit $[92,93]$. In the study of Han et al., BV shows bacteriostatic as well as bactericidal effects against $P$. acnes, clindamycin-resistant $P$. acnes, $S$. epidermidis, and $S$. pyrogenes. In this study, minimum inhibitory concentrations (MIC) of BV against P. acnes, clindamycin-resistant P. acnes, S. epidermidis, and S. pyrogenes were $0.086 \mu \mathrm{g} / \mathrm{mL}, 0.067 \mu \mathrm{g} / \mathrm{mL}, 0.104 \mu \mathrm{g} / \mathrm{mL}$, and $0.121 \mu \mathrm{g} / \mathrm{mL}$, respectively [33].

\subsubsection{Staphylococcus aureus and Methicillin-Resistant Staphylococcus aureus (MRSA)}

Staphylococcus aureus is the main causative pathogen of Impetigo [94], Paronychia [95], and Staphylococcal-scalded skin syndrome [96]. BV exhibited a significant antibacterial effect against S. aureus in an in-vitro study using the disc diffusion method [11]. Although antibiotics effectively deal with S. aureus infections these days, the appearance of methicillin-resistant S. aureus (MRSA) is posing a challenge to global health systems at present [97].

In the study of Han et al. that investigated the antimicrobial effect of BV on MRSA strain in terms of minimum inhibitory concentrations (MIC) and minimum bactericidal concentrations (MBC), the MIC values of BV against MRSA CCARM 3366 and MRSA CCARM 3708 were $0.085 \mu \mathrm{g} / \mathrm{mL}$ and $0.11 \mu \mathrm{g} / \mathrm{mL}$ separately. Its MBC against MRSA 3366 and MRSA 3708 were $0.106 \mu \mathrm{g} / \mathrm{mL}$ and $0.14 \mu \mathrm{g} / \mathrm{mL}$ respectively. Interestingly, MRSA strains were more sensitive to the mix of BV and vancomycin or gentamicin than either ampicillin or penicillin alone. These outcomes showed that BV exhibits antimicrobial and enhancing antibacterial effects versus MRSA strains [13].

Choi et al. examined whether BV and melittin could suppress MRSA infections in vitro and in vivo. Surprisingly, BV showed outstanding antimicrobial effect in vitro, but strengthened the proliferation and infection of MRSA in vivo. All the mice, injected with MRSA USA300 and BV, died $18 \mathrm{~h}$ after infection, while only five died in the control 24 hours after infection. In addition, no outstanding difference was noticed in terms of the diameter of abscesses formed by MRSA USA300 even after BV treatment. 
Unlike BV, melittin showed remarkably better protection in the mice models of bacteremia and skin infection. Half of the mice survived over $24 \mathrm{~h}$ when $5 \mathrm{mg} / \mathrm{kg}$ of melittin was injected 1 hour after bacterial infection and the abscess diameters were notably lower than the control [98].

\subsection{Fungi}

\subsubsection{Dermatophytes, Trichophyton mentagrophytes, and Trichophyton rubrum}

Trichophyton mentagrophytes and Trichophyton rubrum, common dermatophytes, are known to cause various skin infections in humans and animals. Dermatophytes infect keratinized epithelium, the hair and nails. Tinea pedis is described as a dermatophyte infection on the soles of the feet and interdigital spaces; tinea cruris as an infection of the groin; tinea faciei as the facial infection; and tinea corporis as a fungal infection of the rest of the skin [99].

Yu et al. reported that BV showed significant antifungal effects against the two dermatophytes. In this study, $0.63 \mathrm{ppm}$ of BV inhibited the growing of T. menatgrophytes by roughly $92 \%$ and T. rubrum by $26 \%$ after $1 \mathrm{~h}$ of incubation. Furthermore, BV exhibited much stronger antifungal activities than that of fluconazole, a standard antifungal agent utilized for the prevention and management of fungal infections. The results of this study suggest that BV could be developed as a natural antifungal drug [100].

Onychomycosis or tinea unguium which accounts for about half of all nail abnormalities is also caused due to dermatophytes, with the most common agent being Trichophyton rubrum. In the study of Park et al. that investigated the antifungal effects of BV, mellitin, apamin, and BV-based mists on T. rubrum indicated that BV and BV-based mist exhibited strong antifungal effect on T. rubrum. However, the isolated BV components, such as mellitin and apamin, showed no significant effect in hindering the growth of the fungal colonies [101].

\subsubsection{Candida Albicans}

Cutaneous candidiasis is typically caused by Candida albicans, which exists as normal flora of human skin as well as in the gastrointestinal and genitourinary systems [102]. In the study of Lee et al., Sweet BV (SBV), which is made by removing enzymes and histamine known as allergens from BV, and BV exhibited an antifungal effect against 10 clinical isolates of $C$. albicans that were incubated from blood and the vagina.

In this study, SBV was noted to have much stronger antifungal activity than that of BV. The MIC values measured by the broth microdilution method diverge from $62.5 \mu \mathrm{g} / \mathrm{mL}$ to $125 \mu \mathrm{g} / \mathrm{mL}$ for BV, and in the case of SBV, from $15.63 \mu \mathrm{g} / \mathrm{mL}$ to $62.5 \mu \mathrm{g} / \mathrm{mL}$. on the kill-curve assay, SBV acted similar to amphotericin B that was utilized as a positive control [103].

Park et al. demonstrated that melittin exerts its antifungal effect by inducing apoptosis. C. albicans treated with melittin exhibited an increase of ROS. In addition, markers that are indicators of apoptosis in yeast, involving externalization of phosphatidylserine, and fragmentation of DNA and nucleus fragmentation were observed. This study suggests that melittin exerts an antifungal effect by promoting apoptosis [104].

\subsubsection{Malassezia furfur}

Malassezia furfur, a lipophilic yeast-like fungus exists as an opportunistic pathogen in human skin and causes disorders such as dandruff and pityriasis versicolor.

In the study of Prakash et al., wherein $5 \mathrm{mg} / \mathrm{mL}$ BV was loaded onto the disc spread with M. furfur, a large zone of inhibition with an area of $86.9 \mathrm{~mm}^{2}$ was observed. Ketoconazole $(200 \mathrm{mg} / \mathrm{mL})$ was used as a standard reference and it showed an area of inhibition of $156.1 \mathrm{~mm}^{2}$. Since the doses of BV were in the range of $1-5 \mathrm{mg} / \mathrm{mL}$, ketoconazole was applied at $5 \mathrm{mg} / \mathrm{mL}$ and it exhibited a suppression zone of $38.8 \mathrm{~mm}^{2}$. 
In this study, BV showed good inhibition against $M$. furfur. Shampoos that can be bought in the commercial market are mostly made of chemicals and have many side effects. Therefore, supplements with natural compounds such as BV can be a better treatment for skin diseases caused by M. furfur. [105].

\subsection{Viruses}

\section{Herpes Simplex Virus}

Herpes simplex virus (HSV) invades skin and mucous membranes, harming keratinocytes and causing severe inflammation which is accompanied by small blister on the Erythema. Genital infections are mainly caused by HSV-2, while infections of other areas and the mouth are mostly caused by HSV-1 [106].

In the study of Uddin et al., a non-cytotoxic quantity of BV significantly suppressed the replication of HSV. These antiviral properties are mainly based on the virucidal activity of BV. Apart from antiviral activity, BV stimulated IFN-1, which could subsequently initiate antiviral signaling in the host cell and additionally suppress the replication of the virus.

Uddin et al. also examined the antiviral effect of several components of BV to know which compounds in BV played a critical role in the virucidal effect of BV. Among those, only melittin in non-cytotoxic amounts exhibited similar effects to BV. Melittin directly destabilized the structure of virus particle, thereby suppressing viral infectivity. However, melittin was unable to interrupt the cell attachment and entry of the virus into the cells, and hence, once the cells were infected, it could not suppress viral infection and replication [12]. These results indicate that BV or melittin has the possibility to be a prophylactic or therapeutic agent in viral skin diseases.

\section{Therapeutic Mechanisms of BV on Skin Diseases}

Collective evidence from in-vitro experiments, in-vivo studies and clinical trials showed that BV has a potential therapeutic effect on skin diseases. The therapeutic mechanisms of BV mentioned above are as follows:

(1) In acne, TNF- $\alpha$, IL-1 $\beta$, TLR2, and CD14 expressions were remarkably decreased by BV treatment in P. acnes-injected tissues. In addition, the DNA-binding activity of NF- $\mathrm{kB}$ and AP-1 was noticeably inhibited by BV treatment [28]. BV reduced the expression of IL-8, TNF- $\alpha$, and IFN- $\gamma$ in $\mathrm{HaCaT}$ (keratinocyte) and THP-1 (monocytes) cells. It also suppressed TLR2 expression induced by heat-killed P. acnes in HaCaT and THP-1 cells [107]. Melittin significantly decreased TNF- $\alpha$ and IL-1 $\beta$ expression, leading to a noticeable suppression of TLR2 and CD14 expression in keratinocytes [31].

(2) In alopecia, BV promotes hair growth by reducing $5 \alpha$-reductase expression and increasing KGF which stimulates follicular proliferation. BV increases the proliferation of hDPCs and upregulates growth factors, such as FGF7, FGF2, IGF-1, and VEGF, which maintain hair follicles in the anagen phase [35].

(3) In AD, BV suppressed the inflammatory cytokines by decreasing IgE, TNF- $\alpha$, and TSLP levels. It also suppressed the infiltration of mast cells and eosinophils [50]. BV significantly increased the secretion of CD55, a complement formation inhibitor, from THP-1 cells, resulting in a significant reduction in serum C3C and MAC levels, which were evaluated as an indicator of complement system activation [51]. BV significantly inhibited mast cell degranulation and synthesis of pro-inflammatory cytokines, like TNF- $\alpha$ and IL-1 $\beta$, by downregulating NF-kB activation [47]. The propagation and infiltration of T lymphocyte and the production of IL-4 and IgE, which are induced by Th2 type allergic responses, were suppressed by BV treatment [53].

Melittin decreased CD4+ T lymphocytes, mast cell infiltration and serum levels of IgE, IFN- $\gamma$, IL-4, and TSLP. Melittin also suppressed the production of chemokines, like CCL17 and CCL22, and pro-inflammatory cytokines involving IL- 6 , IL- $1 \beta$, and IFN- $\gamma$ by inhibiting the activation of NF- $\mathrm{KB}$, STAT1, and STAT3 signaling pathways in keratinocytes [54]. Moreover, melittin inhibited filaggrin deficiency induced by IL-4 and IL-13 in keratinocytes. In addition, it suppressed mast cell 
infiltration and AD-related inflammatory molecules, such as CD14, CD11b, IL- $1 \beta$, TNF- $\alpha$, and TSLP and exaggerated IgE response [55]. The application of PLA2 significantly suppressed the increase in serum IgE and Th1 and Th2 cytokines. It also attenuated the infiltration of mast cells and histological changes [58].

(4) In melanoma, BV induced fluctuation in intracellular $\mathrm{Ca}^{2+}$ concentrations which increased the levels of ROS and collapse of membrane potential of mitochondria. As a result, AIF and EndoG are translocated from mitochondria into the nucleus to initiate apoptosis [60]. Melittin, loaded on targeted nanoparticles, induced apoptosis of cancer cell via release of cytochrome c from mitochondria [61].

(5) In morphea, the therapeutic mechanism of BV has not been studied yet.

(6) In photoaging, BV significantly decreased UVB-induced MMP-1 and MMP-3 expression in HDFs [67]. BV also decreased the levels of MMP-1 and MMP-13 in HaCaT cells, and MMP-1, -2 , and -3 in HDF cells, which are induced by UVB. Moreover, cell damage and production of collagen were restored by BV treatment. Furthermore, BV treatment downregulated UVB0-induced activation of p38 and ERK1/2 in HaCaT and HDF cells [68].

(7) In psoriasis, a notable reduction in the serum level of IL- $1 \beta$ was observed upon BV treatment [71].

(8) In skin wound healing, BV treatment elevated type 1 collagen expression and decreased the levels of TGF- $\beta 1$, VEGF, and fibronectin, which are cytokines associated with fibrosis [79]. In diabetic wound healing, BV treatment markedly restored type 1 collagen expression. BV significantly decreased the percentage of apoptotic macrophages. In addition, BV promotes angiogenesis via recovering Ang-1/Tie-2 signaling and increasing the expression of Nrf2, ERK, Akt/eNOS and $\beta$-defensin-2, which are normally downregulated in wounded tissues [82].

(9) In wrinkled skin, the therapeutic mechanism of BV action is yet to be explored.

(10) In vitiligo, BV significantly increased melanocyte proliferation, melanogenesis, dendricity, and migration. Hence, BV activated PKA, ERK, and PI3K/Akt signaling and increased MITF-M protein expression [89]. 
Table 1. Clinical study on therapeutic application of bee venom for skin disease.

\begin{tabular}{|c|c|c|c|c|c|c|}
\hline Disease & Model & $\begin{array}{l}\text { Venom/Compound/(Bee } \\
\text { Species) }\end{array}$ & $\begin{array}{c}\text { Dose (Administration } \\
\text { Method) }\end{array}$ & Results & $\begin{array}{c}\text { Mechanism/Molecular } \\
\text { Response }\end{array}$ & Reference \\
\hline Acne & $\begin{array}{l}\text { Human DB, RCT } \\
\qquad(\mathrm{n}=12)\end{array}$ & $\begin{array}{l}\text { Cosmetic containing } \\
\text { BV (Apis melifera) }\end{array}$ & $\begin{array}{l}0.06 \mathrm{mg} / \mathrm{mL} \text {, Cosmetic } 4 \mathrm{~mL} \\
\text { twice daily for } 2 \text { weeks } \\
\text { (Applied to whole face) }\end{array}$ & $\begin{array}{l}\text { Significant improvement of KAGS } \\
\text { score }(p<0.01) \\
57.5 \% \text { decrease of ATP level which } \\
\text { indicate MO level }(p<0.01)\end{array}$ & Not reported & [24] \\
\hline Acne & Human $(n=30)$ & $\begin{array}{l}\text { Serum containing BV } \\
\quad \text { (Apis melifera) }\end{array}$ & $\begin{array}{l}\text { Not reported, Serum } \\
0.7-0.9 \text { g twice daily for } \\
6 \text { weeks (Applied to } \\
\text { whole face) }\end{array}$ & $\begin{array}{l}\text { Significant improvement }(52.3 \%) \text { of } \\
\text { MCAGS score after } 6 \text { weeks } \\
(p<0.001) \\
\text { Open and closed comedones were } \\
\text { significantly decreased }(p<0.001) . \\
\text { Significant decrease in papules } \\
\qquad(p<0.05)\end{array}$ & Not reported & [25] \\
\hline Atopic dermatitis & $\begin{array}{l}\text { Human DB, RCT } \\
\quad(\mathrm{n}=114)\end{array}$ & $\begin{array}{l}\text { Emollient containing } \\
\text { BV (Apis melifera) }\end{array}$ & $\begin{array}{l}\text { Not reported, twice daily } \\
\text { for } 4 \text { weeks (Applied to } \\
\text { entire body) }\end{array}$ & $\begin{array}{l}\text { Remarkable reduction of EASI score } \\
\text { in comparison to control }(p<0.05) \text {. } \\
\text { VAS score for pruritus was notably } \\
\text { declined compared with control } \\
\quad(p<0.05) \text {. } \\
\text { TEWL value were not notably } \\
\text { different between two groups. }\end{array}$ & Not reported & [49] \\
\hline Psoriasis & $\begin{array}{l}\text { Human RLPP } \\
\text { patients DB, RCT } \\
\quad(\mathrm{n}=50)\end{array}$ & BV (Apis melifera) & $\begin{array}{l}0.05 \mathrm{~mL} / \mathrm{cm}^{2} \text { (intradermal } \\
\text { injection around } \\
\text { psoriatic lesion) }\end{array}$ & $\begin{array}{c}\text { BV treatment group showed } \\
\text { significant lower PGA scores against } \\
\text { placebo group }(p<0.001) \text {. } \\
\text { During the follow-up period of } 6 \\
\text { months, psoriasis did not recur. }\end{array}$ & $\begin{array}{l}\text { TNF- } \alpha \text { was notably } \\
\text { decreased compared to } \\
\text { control }(p<0.05) \text {. }\end{array}$ & [75] \\
\hline Psoriasis & $\begin{array}{l}\text { Human patients with } \\
\text { localized plaque } \\
\text { psoriasis }(n=48)\end{array}$ & BV (Apis melifera) & $\begin{array}{c}\text { Starting with } 0.01 \mu \mathrm{L}, \\
\text { increasing } 0.01 \mu \mathrm{L} \text { every } \\
\text { injection untill arriving } 1 \\
\mu \mathrm{L} \text { (Intradermal, } \\
\text { twice weekly) } \\
\text { TP: topical propolis } \\
\text { twice daily } \\
\text { OP: oral propolis } 1 \mathrm{~g} / \text { day } \\
\text { by capsule }\end{array}$ & $\begin{array}{l}\text { PASI score was significantly } \\
\text { decreased decreased after treatment } \\
\qquad(p<0.01) \text {. } \\
\text { Much more reduction than TP } \\
\text { and OP. } \\
\text { The highest reduction in } \\
\text { (TP + OP + BV) group. }\end{array}$ & $\begin{array}{c}\text { Serum IL-1 } \beta \text { was } \\
\text { significantly decreased } \\
\text { after treatment }(p<0.05) \text {. } \\
\text { Much more decrease than } \\
\text { TP and OP.The highest } \\
\text { decrease in } \\
\text { (TP + OP + BV) group. }\end{array}$ & [71] \\
\hline
\end{tabular}


Table 1. Cont.

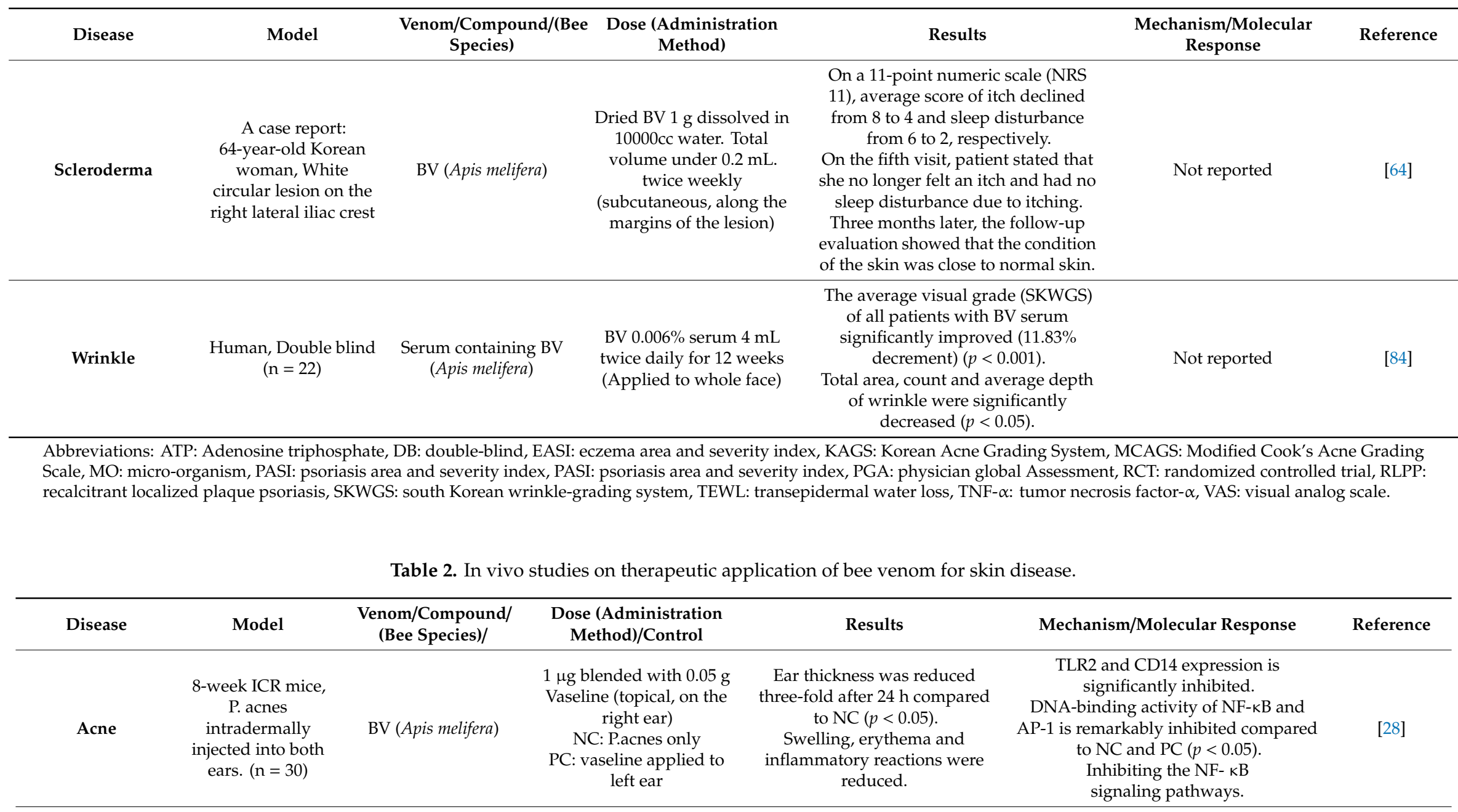


Table 2. Cont.

\begin{tabular}{|c|c|c|c|c|c|c|}
\hline Disease & Model & $\begin{array}{l}\text { Venom/Compound/ } \\
\text { (Bee Species)/ }\end{array}$ & $\begin{array}{l}\text { Dose (Administration } \\
\text { Method)/Control }\end{array}$ & Results & Mechanism/Molecular Response & Reference \\
\hline Acne & $\begin{array}{l}\text { 8-week ICR mice, } \\
\text { P. acnes } \\
\text { intradermally } \\
\text { injected into both } \\
\text { ear. }(\mathrm{n}=30)\end{array}$ & Melittin (Apis melifera) & $\begin{array}{c}100 \mu \mathrm{g} \text { blended with } 0.05 \\
\text { g Vaseline (topical, on the } \\
\text { right ear) } \\
\text { NC: P.acnes only } \\
\text { PC: vaseline applied to } \\
\text { left ear }\end{array}$ & $\begin{array}{c}\text { Ear thickness was reduced } \\
\text { 1.3-fold after } 24 \mathrm{~h} \text { compared } \\
\text { with NC }(p<0.05) \text {. } \\
\text { Swelling and granulomatous } \\
\text { response were markedly } \\
\text { reduced. }\end{array}$ & $\begin{array}{l}\text { Significant reduction of TNF- } \alpha, \text { IL- } 1 \beta \text {, } \\
\text { IL-8, IFN- } \gamma \text { compared with NC and PC } \\
\qquad(p<0.05) \text {. } \\
\text { DNA-binding activity of NF- } \kappa B \text { and } \\
\text { AP-1 is remarkably inhibited compared } \\
\text { to NC and PC }(p<0.05) \text {. } \\
\text { Melittin significantly reduced the } \\
\text { phosphorylation of IKK, I } \kappa B \text { and NF- } \kappa B \text {. } \\
\text { Inhibiting the NF- } \kappa \text { B and MAPK } \\
\text { signaling pathways. }\end{array}$ & [31] \\
\hline Alopecia & $\begin{array}{c}\text { 6-week female } \\
\text { C57BL/6 mice, } \\
\text { catagen phase } \\
\text { induced on dorsal } \\
\text { skin by } \\
\text { dexamethasone. }\end{array}$ & $\mathrm{BV}$ (Apis melifera) & $\begin{array}{c}\text { Three CONC: } \\
0.001 \% 0.005 \% 0.01 \% 100 \\
\mu \mathrm{L} \text { each Once daily for } 19 \\
\text { day (Applied to } \\
\quad \text { dorsal skin) } \\
\text { NC:dexamethasone only } \\
\text { PC: } \text { minoxidil } 2 \% 100 \mu \mathrm{L}\end{array}$ & $\begin{array}{l}\text { Hair growth promoted notably } \\
\text { in a dose-dependent manner at } \\
\text { all doses. } \\
0.01 \% \text { BV resulted in the } \\
\text { greatest increase in hair growth } \\
\text { compared to PC }(p<0.05) .\end{array}$ & $\begin{array}{c}\text { KGF expression is significantly } \\
\text { increased compared with NC }(p<0.05) \text {. } \\
5 \alpha \text {-reductase significantly decreased } \\
\text { compared with NC }(p<0.05) .\end{array}$ & [35] \\
\hline Atopic dermatitis & $\begin{array}{l}\text { DNCB induced } \\
\text { atopic dermatitis } \\
\text { in } 7 \text {-week male } \\
\text { Balb/c mice }(\mathrm{n}=8)\end{array}$ & $\mathrm{BV}$ (Apis melifera) & $\begin{array}{c}0.3 \mathrm{mg} / \mathrm{kg} \\
\text { (subcutaneous) PBS }\end{array}$ & $\begin{array}{c}\text { Dryness, hemorrhage, } \\
\text { excoriation, edema and redness } \\
\text { were almost } \\
\text { completely restored. }\end{array}$ & $\begin{array}{l}\text { Serum C3C and MAC were significantly } \\
\text { decreased after BV injection compared } \\
\text { to PBS injection }(p<0.001) \text {. } \\
\text { Serum-secreted CD55 were significantly } \\
\text { elevated compared with PBS injection } \\
(p<0.001) \text {. } \\
\text { BV increased CD55 production in } \\
\text { THP-1 cells }\end{array}$ & [51] \\
\hline Atopic dermatitis & $\begin{array}{l}\text { OVA-induced } \\
\text { atopic dermatitis } \\
\text { in 6-week female } \\
\text { Balb/c mice } \\
(\mathrm{n}=25)\end{array}$ & $\mathrm{BV}$ (Apis melifera) & $\begin{array}{c}\text { Three doses: } \\
1 \mu \mathrm{g} / \mathrm{Kg}, \\
10 \mu \mathrm{g} / \mathrm{Kg}, 100 \mu \mathrm{g} / \mathrm{Kg} \\
\text { twice a week for } 2 \text { weeks } \\
\text { (intraperitoneal) } \\
\text { NC: untreated PC: } \\
\text { OVA only }\end{array}$ & $\begin{array}{l}\text { Bleeding, erythema, eczema, } \\
\text { and dryness were } \\
\text { significantly reduced. } \\
\text { Dorsal skin thickness was } \\
\text { remarkably reduced in a } \\
\text { dose-dependent manner } \\
\text { compared to PC }(p<0.05) \text {, the } \\
\text { greatest decrease in BV } \\
100 \text { group. }\end{array}$ & $\begin{array}{l}\text { Significant reduction of mast cell } \\
\text { infiltration in BV } 10 \text { and } 100 \text { group } \\
\text { compared with PC }(p<0.05) \text {. } \\
\text { Serum IgE levels were reduced, the } \\
\text { greatest decrease in BV } 100 \text { group. } \\
\text { Significant reduction of TNF- } \alpha \text { in BV } 10 \\
\text { and } 100 \text { and TSLP in BV } 100 \text { group } \\
\text { compared with PC }(p<0.05) .\end{array}$ & [50] \\
\hline
\end{tabular}


Table 2. Cont.

\begin{tabular}{|c|c|c|c|c|c|c|}
\hline Disease & Model & $\begin{array}{l}\text { Venom/Compound/ } \\
\text { (Bee Species)/ }\end{array}$ & $\begin{array}{l}\text { Dose (Administration } \\
\text { Method)/Control }\end{array}$ & Results & Mechanism/Molecular Response & Reference \\
\hline Atopic dermatitis & $\begin{array}{l}\text { DNCB induced } \\
\text { atopic dermatitis } \\
\text { in 6-week female } \\
\text { Balb/c mice } \\
(\mathrm{n}=45)\end{array}$ & Melittin (Apis melifera) & $\begin{array}{c}\text { Three doses: } \\
100 \mu \mathrm{g}, \\
200 \mu \mathrm{g}, \\
500 \mu \mathrm{g} \text { blended with } \\
\text { placebo (topical, to } \\
\text { dorsal skin) } \\
\text { Placebo only }\end{array}$ & $\begin{array}{l}\text { Dorsal skin thickness was } \\
\text { notably decreased in } \\
\text { comparison to placebo group } \\
\quad(p<0.05)\end{array}$ & $\begin{array}{l}\text { Mast cell infiltration was significantly } \\
\text { decreased compared with control } \\
\qquad(p<0.05) \text {. } \\
\text { Serum IFN- } \gamma \text {, IL-4, IgE and TSLP were } \\
\text { markedly decreased in melittin } 200 \text { and } \\
500 \text { group compared to placebo group } \\
(p<0.05) \text {. } \\
\mathrm{CD}^{+} \text {and CD3 } \\
\text { decreased in melittin } 500(p<0.05) \text {. }\end{array}$ & [54] \\
\hline Atopic dermatitis & $\begin{array}{c}\text { Chicken } \\
\text { OVA-induced } \\
\text { atopic dermatitis } \\
\text { in 6-week female } \\
\text { Balb/c mice } \\
(\mathrm{n}=25)\end{array}$ & Melittin (Apis melifera) & $\begin{array}{c}\text { Three CONC: } \\
1 \mu \mathrm{g} / \mathrm{Kg}, \\
10 \mu \mathrm{g} / \mathrm{Kg}, \\
100 \mu \mathrm{g} / \mathrm{Kg} \\
\text { (intraperitoneal) } \\
\text { NC: untreated PC: } \\
\text { OVA only }\end{array}$ & $\begin{array}{l}\text { Dorsal skin thickness was } \\
\text { significantly reduced in } \\
\text { comparison to PC }(p<0.05) \text {, } \\
\text { the greatest decrease in BV } \\
100 \text { group. } \\
\text { Edema, erythema and } \\
\text { excoriation were improved in } \\
\text { melittin group. }\end{array}$ & $\begin{array}{c}\text { Melittin significantly improved } \\
\text { OVA-induced filaggrin deficiency } \\
(p<0.05) \text {. } \\
\text { CD14 and CD11b were significantly } \\
\text { decreased in melittin } 100 \text { group } \\
\text { compared to PC }(p<0.05) \text {. } \\
\text { Mast cell infiltration was remarkably } \\
\text { decreased in melittin } 10 \text { and } 100 \text { group } \\
\text { compared to PC }(p<0.05) \text {. } \\
\text { Serum IL-1 } \beta \text {, TNF- } \alpha \text { was notably } \\
\text { decreased in all dose compared to PC } \\
\text { ( } p<0.05) \text {. } \\
\text { Serum TSLP was remarkably decreased } \\
\text { in melittin } 100 \text { compared to PC ( } p<0.05) \text {. } \\
\text { Skin IL-13 mRNA was significantly } \\
\text { declined in melittin } 100 \text { compared with } \\
\text { PC }(p<0.05) .\end{array}$ & [55] \\
\hline Atopic dermatitis & $\begin{array}{l}\text { DFE/DNCB-induced } \\
\text { atopic dermatitis } \\
\text { in 7-8-week } \\
\text { female Balb/c } \\
\text { mice }(\mathrm{n}=25)\end{array}$ & PLA2 (Apis melifera) & $\begin{array}{c}\text { Two doses: } \\
16 \text { ng/ear, } \\
80 \text { ng/ear } \\
\text { (Applied to ear skin) } \\
\text { NC: DFE/DNCB only PC } \\
\text { :dexamethasone } \\
50 \mu \mathrm{g} / \text { ear }\end{array}$ & $\begin{array}{c}\text { Ear thickness was notably } \\
\text { decreased in all doses } \\
\text { compared to NC }(p<0.001), \\
\text { not more than PC. } \\
\text { AD-like skin lesions were } \\
\text { significantly suppressed } \\
\text { by PLA2. }\end{array}$ & $\begin{array}{c}\text { Th1 cytokines (TNF- } \alpha \text {, IL- } 6 \text { and IFN-) } \\
\text { and Th2 cytokines (IL-4 and IL-13) were } \\
\text { remarkably decreased in comparison to } \\
\text { NC ( } p<0.05) \text {, no more effective than PC. } \\
\text { Epidermal hyperplasia and lymphocyte } \\
\text { infiltration were significantly attenuated } \\
\text { by PLA2 in a dose-dependent manner } \\
\text { compared with control } \\
(p<0.01-p<0.05) \text {, no more effective } \\
\text { than PC. } \\
\text { PLA2 has the potential to counteract } \\
\text { AD-like skin lesion-associated } \\
\text { inflammation responses via the } \\
\text { induction of Tregs. }\end{array}$ & [58] \\
\hline
\end{tabular}


Table 2. Cont.

\begin{tabular}{|c|c|c|c|c|c|c|}
\hline Disease & Model & $\begin{array}{l}\text { Venom/Compound/ } \\
\text { (Bee Species)/ }\end{array}$ & $\begin{array}{l}\text { Dose (Administration } \\
\text { Method)/Control }\end{array}$ & Results & Mechanism/Molecular Response & Reference \\
\hline Atopic dermatitis & $\begin{array}{c}\text { Compound } \\
48 / 80 \text {-induced } \\
\text { atopic dermatitis } \\
\text { in 6-week Balb/c } \\
\text { mice }(\mathrm{n}=32) \text {. }\end{array}$ & BV (Apis melifera) & $\begin{array}{l}\text { Two doses: } \\
0.01 \mathrm{mg} / \mathrm{Kg} \\
0.1 \mathrm{mg} / \mathrm{Kg} \\
\text { (intraperitoneal) } \\
\text { PC: Compound } \\
\text { 48/80 only }\end{array}$ & $\begin{array}{c}\text { Scratching behavior caused by } \\
\text { compound } 48 / 80 \text { was } \\
\text { decreased by } 75 \% \text { and } 87 \% \\
\text { compared with PC in BV } 0.01 \\
\text { and } 0.1 \text { respectively. }(p<0.05) \\
\text { Vascular permeability of the } \\
\text { skin was decreased by } 33.3 \% \\
\text { and } 70.7 \% \text { compared with PC } \\
\text { in BV } 0.01 \text { and } 0.1 \text { respectively. } \\
\qquad(p<0.05)\end{array}$ & $\begin{array}{c}\text { Mast cell degranulation was remarkably } \\
\text { decreased in a dose-dependent manner } \\
\text { compared to PC }(p<0.05) \text {. } \\
\text { TNF- } \alpha \text { and IL-1 } 1 \beta \text { were significantly } \\
\text { suppressed in skin tissue by } \\
\text { BV treatment. } \\
\text { BV inhibited activation of NF- } \mathrm{kB} \text {, which } \\
\text { was induced by compound } 48 / 80 \text {. }\end{array}$ & [47] \\
\hline Atopic dermatitis & $\begin{array}{c}\text { Trimellitic } \\
\text { anhydride } \\
\text {-induced atopic } \\
\text { dermatitis on ear } \\
\text { skin in 10-week } \\
\text { male Balb/c mice } \\
\quad(\mathrm{n}=50) \text {. }\end{array}$ & BV (Apis melifera) & $\begin{array}{c}0.3 \mathrm{mg} / \mathrm{Kg} \text {, } \\
\text { Once daily for } 14 \text { day } \\
\text { (subcutaneous, } \\
\text { acupuncture bilateral } \\
\text { point BL40) } \\
\text { NC: TMA treated } \\
\text { PC: prednisone } \\
\text { BVNA: BV at non } \\
\text { acupoint; base of tail }\end{array}$ & $\begin{array}{l}\text { BV at BL40 acupoint } \\
\text { significantly relieved the } \\
\text { AD symptoms. } \\
\text { Thickness of ear and weight of } \\
\text { lymph node were remarkably } \\
\text { decreased compared to NC } \\
\text { ( } p<0.001) \text {. } \\
\text { All results not better than PC } \\
\text { but similar to BVNA indicated } \\
\text { no healing effect on AD-like } \\
\text { symptoms. }\end{array}$ & $\begin{array}{l}\text { Serum IL-4 and IgE was notably } \\
\text { declined compared to NC }(p<0.001) \text {. } \\
\text { Number of CD4 and CD8 positive cells } \\
\text { was notably declined in comparison to } \\
\text { NC ( } p<0.01) \text {. } \\
\text { TNF- } \alpha \text {, IFN- } \gamma \text {, IL-2, IL-4, IL-10 and IL-12 } \\
\text { concentration in auricular lymph node } \\
\text { were remarkably decreased compared to } \\
\text { NC }(p<0.001-p<0.05) \text {. }\end{array}$ & {$[53]$} \\
\hline Melanoma & $\begin{array}{l}\text { B16F10 murine } \\
\text { melanoma was } \\
\text { implanted } \\
\text { subcutaneously in } \\
\text { C57BL/6 mice } \\
(\mathrm{n}=15)\end{array}$ & Melittin (Apis melifera) & $\begin{array}{c}8.5 \mathrm{mg} / \mathrm{Kg}, 4 \text { injections } \\
\text { every other day starting } \\
\text { at day } 5 \text { (intravenous, } \\
\text { Melittin is loaded on } \\
\text { molecularly targeted } \\
\text { nanoparticles.) } \\
\text { S: saline only } \\
\mathrm{N} \text { : nanoparticle only }\end{array}$ & $\begin{array}{c}\text { Tumor weight was significantly } \\
\text { decreased on day } 14 \text { compared } \\
\text { with } \mathrm{S}(\sim 88 \% \text { reduction }) \text { and } \mathrm{N} \\
(\sim 87 \% \text { reduction })(p<0.01) \text {. } \\
\text { Decrease in the number of } \\
\text { blood vessels in proliferating } \\
\text { cells, and significant areas of } \\
\text { necrosis in } \\
\text { melittin-treated-tumor. }\end{array}$ & $\begin{array}{l}\text { Melittin-loaded nanoparticles cause } \\
\text { apoptosis of cancer cell via release of } \\
\text { cytochrome c from mitochondria. }\end{array}$ & [61] \\
\hline $\begin{array}{l}\text { Wound (Diabetic } \\
\text { wound) }\end{array}$ & $\begin{array}{c}\text { Diabetic } 12 \text {-week } \\
\text { male Balb/c mice } \\
\text { wounded on back } \\
\quad(\mathrm{n}=45)\end{array}$ & $\mathrm{BV}$ (Apis melifera) & $\begin{array}{l}200 \mu \mathrm{g} / \mathrm{kg} \text { for } 15 \text { day } \\
\text { (subcutaneous, on } \\
\text { wound area) } \\
\text { NC: wound on } \\
\text { non-diabetic mice } \\
\text { PC: diabetic mice without } \\
\text { BV treatment }\end{array}$ & $\begin{array}{l}\text { Degree of wound closure was } \\
\text { similar to NC, markedly higher } \\
\text { than PC }(p<0.05) \text {. }\end{array}$ & $\begin{array}{c}\text { Type I collagen expression was } \\
\text { significantly recovered in BV-treated } \\
\text { diabetic mice compared with PC } \\
(p<0.05), \text { lower than NC. } \\
\text { Ang-1, Nrf2, p-Tyr, p-eNOS, p-AKT, } \\
\text { p-ERK, CD31, CCL2, CCL3, CXCL2 and } \\
\beta \text {-Defensin-2 expression were } \\
\text { significantly recovered in BV-treated } \\
\text { diabetic mice compared with PC } \\
(p<0.05) .\end{array}$ & [82] \\
\hline
\end{tabular}


Table 2. Cont.

\begin{tabular}{|c|c|c|c|c|c|c|}
\hline Disease & Model & $\begin{array}{l}\text { Venom/Compound/ } \\
\text { (Bee Species)/ }\end{array}$ & $\begin{array}{l}\text { Dose (Administration } \\
\text { Method)/Control }\end{array}$ & Results & Mechanism/Molecular Response & Reference \\
\hline Wound & $\begin{array}{l}\text { 7-week male HR-1 } \\
\text { mice wounded on } \\
\text { back }(n=30)\end{array}$ & $\mathrm{BV}$ (Apis melifera) & $\begin{array}{c}1 \mu \mathrm{g} / \text { gauze (Wound was } \\
\text { covered with an equal } \\
\text { size of gauze treated with } \\
\text { BV for } 7 \text { day) } \\
\text { NC: untreatedPC: treated } \\
\text { with Vaseline }\end{array}$ & $\begin{array}{l}\text { Dramatic decrease of wound } \\
\text { size was observed in BV group } \\
\text { compared to NC and PC } \\
(p<0.05)\end{array}$ & $\begin{array}{l}\text { Type } 1 \text { collagen was remarkably } \\
\text { elevated in BV group in comparison to } \\
\text { NC and Vaseline. } \\
\text { TGF-b1 and fibronectin were } \\
\text { significantly decreased in BV group in } \\
\text { comparison to control and Vaseline. } \\
\text { VEGF was remarkably declined in BV } \\
\text { and PC compared to NC }(p<0.05) \text {. }\end{array}$ & [79] \\
\hline
\end{tabular}

Abbreviations: AP-1: activator protein-1, CONC: concentration, DEX: dexamethasone, DFE: Dermatophagoides farinae extract, DNCB: 1-chloro-2,4-dinitrobenzene, i.p.: intraperitoneally, i.v.: intravenous, KGF: keratinocyte growth factor, MAPKs: mitogen-activated protein kinases, NC: normal control, OVA: ovalbumin, P. acnes: Propionibacterium acnes, PC: positive control, PLA2: phospholipase A2, s.c:. subcutaneous, TGF-b1: transforming growth factor-b1, TNF- $\alpha$ : tumor necrosis factor- $\alpha$, Tregs: regulatory T cell, TSLP: thymic stromal lymphopoietin, VEGF: vascular endothelial growth factor.

Table 3. In vitro studies on the therapeutic application of bee venom for skin disease.

\begin{tabular}{|c|c|c|c|c|c|c|}
\hline Disease & Model & $\begin{array}{l}\text { Venom/Compound/ } \\
\text { (Bee Species) }\end{array}$ & Dose & Results & Mechanism/Molecular Response & Reference \\
\hline Acne & $\begin{array}{l}\text { THP-1 cell dealt with } \\
\text { heat-killed P. acnes }\end{array}$ & $\mathrm{BV}$ (Apis melifera) & $\begin{array}{c}\text { Three CONC: } \\
0.1 \mu \mathrm{g} / \mathrm{mL} \\
1 \mu \mathrm{g} / \mathrm{mL} \\
5 \mu \mathrm{g} / \mathrm{mL} \text { for } 48 \mathrm{~h}\end{array}$ & $\begin{array}{c}\text { Significant reduction of TNF- } \alpha \text {, IL- } 8 \\
\text { in a concentration-dependent } \\
\text { manner }(p<0.05) . \\
\text { Lowest TNF- } \alpha \text { at } 5 \mu \mathrm{g} / \mathrm{mL} \\
\text { Lowest IL- } 8 \text { at } 1 \mu \mathrm{g} / \mathrm{mL}\end{array}$ & Not reported & [32] \\
\hline Acne & $\begin{array}{l}\text { THP-1 cell dealt with } \\
\text { heat-killed P. acnes }\end{array}$ & BV (Apis melifera) & $\begin{array}{c}\text { Three CONC: } \\
1 \mathrm{ng} / \mathrm{mL} \\
10 \mathrm{ng} / \mathrm{mL} \\
100 \mathrm{ng} / \mathrm{mL} \text { for } 8 \mathrm{~h}\end{array}$ & $\begin{array}{c}\text { Significant reduction of TNF- } \alpha \text {, IL-8, } \\
\text { IFN- } \gamma \text { at all doses compared to } \\
\text { control }(p<0.05) \text {. } \\
\text { Reduced in dose dependent manner. }\end{array}$ & $\begin{array}{c}\text { TLR2 expression } \\
\text { significantly suppressed }\end{array}$ & [107] \\
\hline Acne & $\begin{array}{l}\text { THP-1 cell treated } \\
\text { with heat-killed } \\
\text { P. acnes }\end{array}$ & Melittin (Apis melifera) & $\begin{array}{l}\text { Three CONC: } \\
0.1 \mathrm{ng} / \mathrm{mL}, 0.5 \mathrm{ng} / \mathrm{mL}, \\
1 \mathrm{ng} / \mathrm{mL} . \text { for } 8 \mathrm{~h}\end{array}$ & $\begin{array}{l}\text { Significant reduction of TNF- } \alpha \text {, IL-8 } \\
\text { at all doses compared to control } \\
\qquad(p<0.05) \text {. } \\
\text { Reduced in dose-dependent manner. }\end{array}$ & $\begin{array}{l}\text { Melittin significantly reduced the } \\
\text { phosphorylation of IKK, IKB and NF- } \mathrm{kB} \text {. } \\
\text { Inhibiting the NF- } \mathrm{kB} \\
\text { signaling pathways. }\end{array}$ & [107] \\
\hline Acne & $\begin{array}{l}\text { HaCat cell treated } \\
\text { with heat-killed } \\
\text { P. acnes }\end{array}$ & $\mathrm{BV}$ (Apis melifera) & $\begin{array}{l}\text { Three CONC: } \\
1 \mathrm{ng} / \mathrm{mL}, 10 \mathrm{ng} / \mathrm{mL}, \\
100 \mathrm{ng} / \mathrm{mL} \text { for } 8 \mathrm{~h}\end{array}$ & $\begin{array}{l}\text { Significant reduction of TNF- } \alpha, \text { IL-8, } \\
\text { IFN- } \gamma \text { at } 10,100 \mathrm{ng} / \mathrm{mL} \text { in } \\
\text { comparison to control }(p<0.05) \text {. } \\
\text { Reduced in dose-dependent manner. }\end{array}$ & $\begin{array}{c}\text { TLR2 expression } \\
\text { significantly suppressed }\end{array}$ & [107] \\
\hline
\end{tabular}


Table 3. Cont.

\begin{tabular}{|c|c|c|c|c|c|c|}
\hline Disease & Model & $\begin{array}{l}\text { Venom/Compound/ } \\
\text { (Bee Species) }\end{array}$ & Dose & Results & Mechanism/Molecular Response & Reference \\
\hline Acne & $\begin{array}{l}\text { HaCat cell dealt with } \\
\text { heat-killed P. acnes }\end{array}$ & Melittin (Apis melifera) & $1 \mu \mathrm{g} / \mathrm{mL}$ & $\begin{array}{l}\text { Significant reduction of TNF- } \alpha \\
\text { IL-1 } \beta \text {, IL- } 8 \text {, IFN- } \gamma \text { compared with } \\
\text { control }(p<0.05)\end{array}$ & $\begin{array}{c}\text { TLR2 and } 4 \text { expression significantly } \\
\text { decreased. } \\
\text { Melittin significantly reduced the } \\
\text { phosphorylation of IKK, IKB, NF- } \mathrm{KB} \\
\text { and p-38. } \\
\text { Inhibiting the NF- } \mathrm{KB} \text { and MAPK } \\
\text { signaling pathways. }\end{array}$ & [31] \\
\hline Alopecia & $\begin{array}{l}\text { hDPC treated with } \\
0.1 \% \text { dexamethasone }\end{array}$ & BV (Apis melifera) & $\begin{array}{c}\text { Three CONC: } \\
100 \mathrm{ng} / \mathrm{mL}, 200 \mathrm{ng} / \mathrm{mL}, \\
500 \mathrm{ng} / \mathrm{mL} \text { for } 24 \mathrm{~h}\end{array}$ & $\begin{array}{c}\text { Significant increase of FGF-2, FGF-7, } \\
\text { IGF-1R and VEGF compared with } \\
\text { DEX only. } \\
(p<0.001-p<0.05) . \\
\text { Protein-level of VEGF is increased } \\
1.95-, 2.95-, 2.08 \text { and } 1.47-\text { fold with } \\
\text { 100, } 200,500 \mathrm{ng} / \mathrm{mL} \text { BV and } \% \\
\text { minoxidil respectively. }\end{array}$ & Not reported & [35] \\
\hline $\begin{array}{l}\text { Atopic } \\
\text { dermatitis }\end{array}$ & $\begin{array}{l}\text { Hacat cell treated } \\
\text { with TNF- } \alpha \text { and } \\
\text { IFN- } \gamma\end{array}$ & Melittin (Apis melifera) & $\begin{array}{c}\text { Three CONC: } \\
0.1 \mu \mathrm{g} / \mathrm{mL}, 0.5 \mu \mathrm{g} / \mathrm{mL} \\
1 \mu \mathrm{g} / \mathrm{mL} .\end{array}$ & $\begin{array}{c}\text { IL-1 } \beta, \text { IL-6 and IFN- } \gamma \text { were } \\
\text { decreased in a } \\
\text { dose-dependent manner. } \\
\text { mRNA of CCL17 and CCL22 were } \\
\text { significantly decreased in a } \\
\text { dose-dependent manner in melitin } \\
0.5 \text { and } 1 \text { in comparison to control } \\
(p<0.05) \text {. } \\
\text { pJAK2, pSTAT1 and pSTAT3 } \\
\text { expression was decreased in melittin } \\
1 \mu \mathrm{g} / \mathrm{mL}\end{array}$ & $\begin{array}{l}\text { NF- кB DNA-binding activity was } \\
\text { markedly reduced. }\end{array}$ & [54] \\
\hline $\begin{array}{l}\text { Atopic } \\
\text { dermatitis }\end{array}$ & $\begin{array}{l}\text { Hacat cell treated by } \\
50 \mathrm{ng} / \mathrm{mL} \text { of IL-4 } \\
\text { and IL-13 }\end{array}$ & Melittin (Apis melifera) & $\begin{array}{c}\text { Three CONC: } \\
0.1 \mu \mathrm{g} / \mathrm{mL}, 0.5 \mu \mathrm{g} / \mathrm{mL}, \\
1 \mu \mathrm{g} / \mathrm{mL} . \text { for } 24 \mathrm{~h}\end{array}$ & $\begin{array}{l}\text { Filaggrin expression was remarkably } \\
\text { elevated in a dose-dependent } \\
\text { manner in all doses compared to } \\
\text { control }(p<0.05) \\
\text { pSTAT3 expression was significantly } \\
\text { decreased in melittin } 1 \mu \mathrm{g} / \mathrm{mL}\end{array}$ & Not reported & [55] \\
\hline
\end{tabular}


Table 3. Cont.

\begin{tabular}{|c|c|c|c|c|c|c|}
\hline Disease & Model & $\begin{array}{l}\text { Venom/Compound/ } \\
\text { (Bee Species) }\end{array}$ & Dose & Results & Mechanism/Molecular Response & Reference \\
\hline Melanoma & $\begin{array}{l}\text { Human } \\
\text { melanoma } \\
\text { A2058 cells }\end{array}$ & $\mathrm{BV}$ (Apis melifera) & $4 \mu \mathrm{g} / \mathrm{mL}$ & $\begin{array}{l}\text { Application of } 4 \mathrm{mg} / \mathrm{mL} \text { BV for } 2 \mathrm{~h} \text { resulted in } \\
\text { the death of approximately } 80 \% \text { of A2058 cells. }\end{array}$ & $\begin{array}{c}\text { BV generated reactive oxygen species (ROS) } \\
\text { and altered mitochondrial membrane } \\
\text { potential transition. } \\
\text { BV causes apoptosis in AIF/EndoG-dependent } \\
\text { but caspase-independent manner. } \\
\text { BV interfered with AKT and MAPK family } \\
\text { kinase activation. } \\
\text { BV treatment significantly reduced } \\
\text { phosphorylated AKT and p38 BV made ER } \\
\text { and extracellular } \mathrm{Ca}^{2+} \text { drift to the cytosol. }\end{array}$ & {$[60]$} \\
\hline Photoaging & $\begin{array}{l}\text { HDF cell } \\
\text { irradiated by } \\
\text { UVB (312 nm) }\end{array}$ & $\begin{array}{l}\text { PLA2-free BV(PBV) } \\
\text { and BV (Apis melifera) }\end{array}$ & $\begin{array}{c}\text { PBV: } \\
1.5 \mu \mathrm{g} / \mathrm{mL} \\
3.0 \mu \mathrm{g} / \mathrm{mL}, \mathrm{BV} \\
1.5 \mu \mathrm{g} / \mathrm{mL} \\
3.0 \mu \mathrm{g} / \mathrm{mL}\end{array}$ & $\begin{array}{l}\text { Both PBV and BV significantly restored Type } 1 \\
\text { procollagen synthesis in UVB-irradiated HDF } \\
\text { cells except for BV } 3 \mu \mathrm{g} / \mathrm{mL}(p<0.05) \text {. } \\
\text { Type } 1 \text { collagen significantly increased in both } \\
\text { BV, PBV compared with control }(p<0.05) . \\
\text { (Degree: } 3.0 \mathrm{BV}>1.5 \mathrm{BV}>3.0 \mathrm{PBV}>1.5 \mathrm{PBV})\end{array}$ & $\begin{array}{l}\text { PBV and BV treatments significantly } \\
\text { attenuated the MMP-1, } 2 \text { and } 3 \text { expressions } \\
\qquad(p<0.05) \text {. } \\
\text { Both PBV and BV significantly inhibited the } \\
\text { UVB-stimulated phosphorylations of ERK1/2 } \\
\text { and p38 }(p<0.05) \text {. }\end{array}$ & [68] \\
\hline Photoaging & $\begin{array}{l}\text { Hacat cell } \\
\text { irradiated by } \\
\text { UVB (312 nm) }\end{array}$ & $\begin{array}{l}\text { PLA2-free BV(PBV) } \\
\text { and BV (Apis melifera) }\end{array}$ & $\begin{array}{c}\text { PBV: } \\
1.5 \mu \mathrm{g} / \mathrm{mL} \\
3.0 \mu \mathrm{g} / \mathrm{mL}, \mathrm{BV}: \\
1.5 \mu \mathrm{g} / \mathrm{mL} \\
3.0 \mu \mathrm{g} / \mathrm{mL}\end{array}$ & $\begin{array}{l}\text { PBV and BV treatments significantly } \\
\text { attenuated the MMP-1, } 13 \text { expressions } \\
\qquad(p<0.05) . \\
\text { Both PBV and BV significantly inhibited the } \\
\text { UVB-stimulated phosphorylations of ERK1/2 } \\
\text { and p38 }(p<0.05) \text {. }\end{array}$ & & [68] \\
\hline Photoaging & $\begin{array}{l}\text { HDF cell } \\
\text { irradiated by } \\
\text { UVB } \\
(280-350 \mathrm{~nm})\end{array}$ & $\mathrm{BV}$ (Apis melifera) & $\begin{array}{l}\text { Three CONC: } \\
0.01 \mu \mathrm{g} / \mathrm{mL} \\
0.1 \mu \mathrm{g} / \mathrm{mL}, 1 \mu \mathrm{g} / \mathrm{mL} \\
\text { for } 24 \mathrm{~h}\end{array}$ & $\begin{array}{l}\text { BV significantly decreased MMP-1 } \\
\text { expressions by } 50-80 \% \text { while MMP-3 } \\
\text { expression by } 50-85 \% \text { compared to controls } \\
\qquad(p<0.05) \text {. } \\
\text { The biggest MMP- } 1 \text { and MMP-3 inhibitions } \\
\text { were observed at a } 0.1 \mu \mathrm{g} / \mathrm{mL} \text {. }\end{array}$ & Not reported & [67] \\
\hline Vitiligo & $\begin{array}{l}\text { Human } \\
\text { epidermal } \\
\text { melanocyte }\end{array}$ & $\mathrm{BV}$ (Apis melifera) & $10 \mu \mathrm{g} / \mathrm{mL}$ & $\begin{array}{c}\text { Melanocyte proliferation and melanin content } \\
\text { were remarkably increased compared to } \\
\text { control }(p<0.05) \text {, similar to melanocyte } \\
\text { treated with } 10 \mu \mathrm{M} \text { forskolin but no } \\
\text { more than. }\end{array}$ & $\begin{array}{l}\text { Forskolin increased the cAMP level } 40 \text {-fold, } \\
\text { but BV only tripled. Based on this, the cAMP } \\
\text { level does not appear to be the deciding factor }\end{array}$ & [89] \\
\hline
\end{tabular}

Abbreviations: AIF: apoptosis-inducing factor, AKT: protein kinase B, cAMP: cyclic adenosine monophosphate, CONC: concentration, DEX: dexamethasone, EndoG: endonuclease G, ER: endoplasmic reticulum, ERK1/2: extracellular signal-regulated kinase 1 and 2, FGF: fibroblast growth factor, HaCat: human keratocyte, HDF: human dermal fibroblasts, hDPC: human dermal papilla cell, HEK: human epidermal keratinocyte, IGF-1R: insulin-like growth factor 1 receptor, MAPK: mitogen-activated protein kinase, P. acnes: Propionibacterium acnes, pJAK: phosphorylated janus kinases, pSTAT3: phosphorylated signal transducer and activator of transcription, TLR2: Toll-like receptor 2, UVB: ultraviolet, VEGF: vascular endothelial pJAK: phosphory
growth factor. 


\section{Discussion}

Although no severe adverse effects were accounted from the studies reviewed here (Table 4), it cannot be ruled out that BV might cause fatal adverse reactions such as anaphylaxis [108]. Thus, physicians who use BV should be careful when administering BV to patients. In clinics, a skin test is used to determine whether BV treatment is suitable for individual patients, however, negative results of a skin test do not always guarantee safety [109]. Furthermore, one case report showed that anaphylaxis may occur in patients who have had no adverse reaction after former BV therapy [110]. Since anaphylaxis can occur under any circumstances, an emergency kit in accordance with the guidelines for management of anaphylaxis should always be kept ready. Meanwhile, one retrospective case study reported that the mean time to onset of anaphylaxis after BV therapy was $21.75 \mathrm{~min}$ [111], therefore, it is necessary to monitor the patient for at least $30 \mathrm{~min}$ after BV treatment. One recent study reported that high levels of basal serum tryptase increased the risk of severe anaxphylaxis [110]. As per this information, even if an injection of BV did not cause anaphylaxis in the past, if the basal serum tryptase is elevated at a certain time for some reason, anaphylaxis may occur when BV is injected. If this hypothesis is correct, the specific physiological state of the body at the point of BV injection may be a strong risk factor for the development of anaphylaxis. The analysis of safety of BV treatment will be a crucial factor in determining the value of $\mathrm{BV}$ as a therapeutic agent. We hope that further studies on prediction factors to prevent anaphylaxis upon BV administration will be conducted.

Table 4. Adverse effects reported in clinical studies and in in vivo studies.

\begin{tabular}{|c|c|c|c|c|}
\hline Disease & Type of Study & $\begin{array}{c}\text { Venom/Compound/(Bee } \\
\text { Species) }\end{array}$ & $\begin{array}{l}\text { Adverse Effect } \\
\text { (Severity) }\end{array}$ & Reference \\
\hline $\begin{array}{c}\text { Atopic } \\
\text { dermatitis }\end{array}$ & Clinical & $\begin{array}{l}\text { Emollient containing BV } \\
\qquad \text { (Apis melifera) }\end{array}$ & $\begin{array}{l}\text { Irritation, pruritus, } \\
\text { erythema, urticaria } \\
\text { and disease } \\
\text { exacerbation (mild). } \\
\text { No significant } \\
\text { differences in the } \\
\text { incidence compared } \\
\text { with control. }\end{array}$ & [49] \\
\hline Psoriasis & Clinical & BV (Apis melifera) & $\begin{array}{l}\text { Mild pain, redness and } \\
\text { swelling at the site of } \\
\text { apitheraphy injection }\end{array}$ & [75] \\
\hline Psoriasis & Clinical & BV (Apis melifera) & $\begin{array}{c}\text { 4patients experienced } \\
\text { itching but not } \\
\text { significant. } \\
\text { No systemic } \\
\text { adverse effect. }\end{array}$ & [71] \\
\hline Scleroderma & Clinical & BV (Apis melifera) & $\begin{array}{l}\text { Slight itchiness at the } \\
\text { location of inoculation } \\
\text { for } 1 \text { half-day. }\end{array}$ & {$[64]$} \\
\hline
\end{tabular}

In this review, we surveyed the reports that showed the cytocidal effect of BV on pathogenic microorganisms that cause skin diseases as well as have a therapeutic effect on skin diseases. BV showed a significant inhibitory effect against various bacteria, fungi and viruses, and these results show potential applications of BV for diseases wherein the microbial agent is the main therapeutic agent. We expect further studies that examine the effect of BV on the treatment of various skin infections.

Treatment of warts by subcutaneous injection of BV is already being practiced in oriental medicine clinics in Korea. So, we believe that there would be a study that shows the therapeutic effects of BV on warts, but there have been no documented reports were warts were treated by using BV. Warts is known to be caused by skin infection with human papilloma virus (HPV). BV may also have a virucidal effect on the HPV virus that causes warts, as it is reported to have antiviral properties [12]. We look 
forward to further research about using BV in the management of warts. Furthermore, we hope that clinicians who use BV for the treatment of skin disorder actively report their cases.

Treatment with natural substances is expected to have fewer side effects than with conventional medicine, but this comparison should ensure sufficient therapeutic effects. Many studies reviewed here have shown the ability of BV to reduce inflammatory cytokines and the disease-causing microbes; however, the status of BV among the current treatments is not very clear. Using current commercial drugs as positive controls in the future studies will help assess the precise therapeutic effect of BV. However, it may not be accurate to conclude that $\mathrm{BV}$ is meaningless as an alternative treatment because conventional medicine shows a greater magnitude of change in vitro studies. Because life has a very complex and organic structure, reactions to certain substances can be different between at the cell level and at the living level. Therefore, in order to ultimately determine whether BV has a therapeutic effect or not, it is necessary to evaluate how much change is made by BV in the lesion in the animal or human, not just in the cell. In addition, even if the efficacy of BV is lower than conventional therapy, it can be valuable as a therapeutic agent if it can make enough improvement of disease.Of course, in-vitro study can easily help in the analysis of molecular mechanisms and it plays an important role in providing hypotheses for follow-up research at a low cost; however, clinical trial and in-vivo study are necessary to decide the dosage and appropriate use of BV. Meanwhile, such studies are also very important in identifying the side effects of BV. Choi et al. conducted in vitro and in vivo studies to examine whether BV and melittin are able to suppress MRSA infections. Surprisingly, BV showed outstanding antimicrobial activity in vitro, but strengthened the proliferation and infection of MRSA in vivo [98]. Among 25 studies on 10 diseases surveyed this time, 15 studies were on acne and AD. The number of studies on the other eight diseases was not sufficient to conclusively assert the therapeutic role of BV. Especially, for vitiligo and photoaging, only in vitro studies have been carried out. We look forward to additional studies in the form of a clinical trials and more in vivo studies for the remaining eight diseases.

In this review, we have tried to investigate not only the therapeutic effects of $\mathrm{BV}$, but also its acting mechanism. In the case of much studied acne and $\mathrm{AD}$, there is considerable information about the mechanism of BV action. However, despite a limited number of studies, therapeutic mechanisms of $\mathrm{BV}$ action in alopecia, melanoma, photoaging, wound healing, and vitiligo were also found. However, no studies have been carried out for morphea, psoriasis and skin wrinkles. Despite many studies, the precise use of BV in treatment has not been accurately identified. We look forward to further studies that examine the molecular mechanism of BV treatment.

This review only dealt with melanoma in relation to skin cancer, but there was also a study that tested the efficacy of melittin in relation to the treatment of squamous cell carcinoma (SCC). SCC has the second highest prevalence of skin cancer after melanoma [112], with 700,000 new cases occurring each year [113]. The major risk factors of SCC are ultraviolet light and ultraviolet light absorbed by skin cells' DNA, including keratinocyte, causing genetic and epigenetic changes in these cells. In particular, studies have shown that p53 and the RAS pathway are responsible for this malignant transformation [114]. Do et al. demonstrated that the combination of melittin and 5-FU, which is used as topical treatment for SCC, increased the cancer-killing effect and reduced the cytotoxicity on normal keratinocyte [115]. Despite delicate data collection, there were studies that were missed. In the data collection process for preparing a review paper, a search method that can scan not only the title of the paper but also the contents of the paper should be considered.

It is not necessary to use only one method to treat diseases nor is it needed to replace the conventional drugs completely with natural substances. We expect that there is potential that a combination of BV and conventional medicine could prove to be a valuable therapeutic asset and could minimize adverse effects. We look forward to various types of follow-up research using BV.

Funding: This research received no external funding.

Conflicts of Interest: The authors declare no conflict of interest. 


\section{References}

1. Son, D.J.; Lee, J.W.; Lee, Y.H.; Song, H.S.; Lee, C.K.; Hong, J.T. Therapeutic application of anti-arthritis, pain-releasing, and anti-cancer effects of bee venom and its constituent compounds. Pharmacol. Ther. 2007, 115, 246-270. [CrossRef] [PubMed]

2. Lee, M.S.; Pittler, M.H.; Shin, B.C.; Kong, J.C.; Ernst, E. Bee venom acupuncture for musculoskeletal pain: A review. J. Pain 2008, 9, 289-297. [CrossRef] [PubMed]

3. Han, C.H.; Lee, Y.S.; Sung, S.H.; Lee, B.H.; Shin, H.Y.; Lee, Y.J. Trend analysis of the research on bee venom acupuncture in south korea, based on published articles. J. Korean Med. 2015, 36, 80-103. [CrossRef]

4. Lee, J.A.; Son, M.J.; Choi, J.; Jun, J.H.; Kim, J.I.; Lee, M.S. Bee venom acupuncture for rheumatoid arthritis: A systematic review of randomised clinical trials. BMJ Open 2014, 4, e006140. [CrossRef] [PubMed]

5. Seo, B.K.; Lee, J.H.; Sung, W.S.; Song, E.M.; Jo, D.J. Bee venom acupuncture for the treatment of chronic low back pain: Study protocol for a randomized, double-blinded, sham-controlled trial. Trials 2013, 14, 16. [CrossRef] [PubMed]

6. Nitecka-Buchta, A.; Buchta, P.; Tabenska-Bosakowska, E.; Walczynska-Dragon, K.; Baron, S. Myorelaxant effect of bee venom topical skin application in patients with $\mathrm{rdc} / \mathrm{tmd}$ ia and $\mathrm{rdc} / \mathrm{tmd} \mathrm{ib}$ : A randomized, double blinded study. Biomed. Res. Int. 2014, 2014, 296053. [CrossRef] [PubMed]

7. Hwang, D.S.; Kim, S.K.; Bae, H. Therapeutic effects of bee venom on immunological and neurological diseases. Toxins 2015, 7, 2413-2421. [CrossRef]

8. Yang, E.J.; Jiang, J.H.; Lee, S.M.; Yang, S.C.; Hwang, H.S.; Lee, M.S.; Choi, S.M. Bee venom attenuates neuroinflammatory events and extends survival in amyotrophic lateral sclerosis models. J. Neuroinflamm. 2010, 7, 69. [CrossRef]

9. Gu, H.; An, H.J.; Kim, J.Y.; Kim, W.H.; Gwon, M.G.; Kim, H.J.; Han, S.M.; Park, I.; Park, S.C.; Leem, J.; et al. Bee venom attenuates porphyromonas gingivalis and rankl-induced bone resorption with osteoclastogenic differentiation. Food Chem. Toxicol. 2019, 129, 344-353. [CrossRef]

10. Zhang, S.; Liu, Y.; Ye, Y.; Wang, X.R.; Lin, L.T.; Xiao, L.Y.; Zhou, P.; Shi, G.X.; Liu, C.Z. Bee venom therapy: Potential mechanisms and therapeutic applications. Toxicon 2018, 148, 64-73. [CrossRef]

11. Zolfagharian, H.; Mohajeri, M.; Babaie, M. Bee venom (apis mellifera) an effective potential alternative to gentamicin for specific bacteria strains: Bee venom an effective potential for bacteria. J. Pharmacopunct. 2016, 19, 225-230. [CrossRef] [PubMed]

12. Uddin, M.B.; Lee, B.H.; Nikapitiya, C.; Kim, J.H.; Kim, T.H.; Lee, H.C.; Kim, C.G.; Lee, J.S.; Kim, C.J. Inhibitory effects of bee venom and its components against viruses in vitro and in vivo. J. Microbiol. 2016, 54, 853-866. [CrossRef] [PubMed]

13. Han, S.M.; Kim, J.M.; Hong, I.P.; Woo, S.O.; Kim, S.G.; Jang, H.R.; Pak, S.C. Antibacterial activity and antibiotic-enhancing effects of honeybee venom against methicillin-resistant staphylococcus aureus. Molecules 2016, 21, 79. [CrossRef] [PubMed]

14. Socarras, K.M.; Theophilus, P.A.S.; Torres, J.P.; Gupta, K.; Sapi, E. Antimicrobial activity of bee venom and melittin against borrelia burgdorferi. Antibiotics 2017, 6, 31. [CrossRef] [PubMed]

15. Lyu, C.; Fang, F.; Li, B. Anti-tumor effects of melittin and its potential applications in clinic. Curr. Protein Pept. Sci. 2019, 20, 240-250. [CrossRef] [PubMed]

16. Rady, I.; Siddiqui, I.A.; Rady, M.; Mukhtar, H. Melittin, a major peptide component of bee venom, and its conjugates in cancer therapy. Cancer Lett. 2017, 402, 16-31. [CrossRef]

17. Memariani, H.; Memariani, M.; Shahidi-Dadras, M.; Nasiri, S.; Akhavan, M.M.; Moravvej, H. Melittin: From honeybees to superbugs. Appl. Microbiol. Biotechnol. 2019, 103, 3265-3276. [CrossRef] [PubMed]

18. Jappe, U. Pathological mechanisms of acne with special emphasis on propionibacterium acnes and related therapy. Acta Derm. Venereol. 2003, 83, 241-248. [CrossRef]

19. Toyoda, M.; Morohashi, M. Pathogenesis of acne. Med. Electron Microsc. 2001, 34, 29-40. [CrossRef]

20. Ochsendorf, F. Systemic antibiotic therapy of acne vulgaris. J. Dtsch. Dermatol. Ges. 2006, 4, 828-841. [CrossRef]

21. Eady, E.A. Bacterial resistance in acne. Dermatology 1998, 196, 59-66. [CrossRef] [PubMed]

22. Eady, E.A.; Cove, J.H.; Holland, K.T.; Cunliffe, W.J. Erythromycin resistant propionibacteria in antibiotic treated acne patients: Association with therapeutic failure. Br. J. Dermatol. 1989, 121, 51-57. [CrossRef] 
23. Tan, H.H. Antibacterial therapy for acne: A guide to selection and use of systemic agents. Am. J. Clin. Dermatol. 2003, 4, 307-314. [CrossRef]

24. Han, S.M.; Lee, K.G.; Pak, S.C. Effects of cosmetics containing purified honeybee (apis mellifera 1.) venom on acne vulgaris. J. Integr. Med. 2013, 11, 320-326. [CrossRef] [PubMed]

25. Han, S.M.; Pak, S.C.; Nicholls, Y.M.; Macfarlane, N. Evaluation of anti-acne property of purified bee venom serum in humans. J. Cosmet. Dermatol. 2016, 15, 324-329. [CrossRef] [PubMed]

26. Leyden, J.J.; McGinley, K.J.; Mills, O.H.; Kligman, A.M. Propionibacterium levels in patients with and without acne vulgaris. J. Investig. Dermatol. 1975, 65, 382-384. [CrossRef] [PubMed]

27. Vowels, B.R.; Yang, S.; Leyden, J.J. Induction of proinflammatory cytokines by a soluble factor of propionibacterium acnes: Implications for chronic inflammatory acne. Infect. Immun. 1995, 63, 3158-3165. [PubMed]

28. An, H.J.; Lee, W.R.; Kim, K.H.; Kim, J.Y.; Lee, S.J.; Han, S.M.; Lee, K.G.; Lee, C.K.; Park, K.K. Inhibitory effects of bee venom on propionibacterium acnes-induced inflammatory skin disease in an animal model. Int. J. Mol. Med. 2014, 34, 1341-1348. [CrossRef] [PubMed]

29. Raghuraman, H.; Chattopadhyay, A. Melittin: A membrane-active peptide with diverse functions. Biosci. Rep. 2007, 27, 189-223. [CrossRef]

30. Lee, G.; Bae, H. Anti-inflammatory applications of melittin, a major component of bee venom: Detailed mechanism of action and adverse effects. Molecules 2016, 21, 616. [CrossRef] [PubMed]

31. Lee, W.R.; Kim, K.H.; An, H.J.; Kim, J.Y.; Chang, Y.C.; Chung, H.; Park, Y.Y.; Lee, M.L.; Park, K.K. The protective effects of melittin on propionibacterium acnes-induced inflammatory responses in vitro and in vivo. J. Investig. Dermatol. 2014, 134, 1922-1930. [CrossRef] [PubMed]

32. Hari, A.; Flach, T.L.; Shi, Y.; Mydlarski, P.R. Toll-like receptors: Role in dermatological disease. Mediat. Inflamm. 2010, 2010, 16. [CrossRef] [PubMed]

33. Han, S.; Lee, K.; Yeo, J.; Baek, H.; Park, K. Antibacterial and anti-inflammatory effects of honeybee (apis mellifera) venom against acne-inducing bacteria. J. Med. Plants Res. 2010, 4, 459-464.

34. Huang, K.P.; Mullangi, S.; Guo, Y.; Qureshi, A.A. Autoimmune, atopic, and mental health comorbid conditions associated with alopecia areata in the united states. JAMA Dermatol. 2013, 149, 789-794. [CrossRef] [PubMed]

35. Park, S.; Erdogan, S.; Hwang, D.; Hwang, S.; Han, E.H.; Lim, Y.H. Bee venom promotes hair growth in association with inhibiting 5alpha-reductase expression. Biol. Pharm. Bull. 2016, 39, 1060-1068. [CrossRef] [PubMed]

36. Yim, E.; Nole, K.L.; Tosti, A. 5alpha-reductase inhibitors in androgenetic alopecia. Curr. Opin. Endocrinol. Diabetes Obes. 2014, 21, 493-498. [CrossRef]

37. Amory, J.K.; Wang, C.; Swerdloff, R.S.; Anawalt, B.D.; Matsumoto, A.M.; Bremner, W.J.; Walker, S.E.; Haberer, L.J.; Clark, R.V. The effect of 5alpha-reductase inhibition with dutasteride and finasteride on semen parameters and serum hormones in healthy men. J. Clin. Endocrinol. Metab. 2007, 92, 1659-1665. [CrossRef] [PubMed]

38. Traish, A.M.; Hassani, J.; Guay, A.T.; Zitzmann, M.; Hansen, M.L. Adverse side effects of 5alpha-reductase inhibitors therapy: Persistent diminished libido and erectile dysfunction and depression in a subset of patients. J. Sex. Med. 2011, 8, 872-884. [CrossRef]

39. Cotsarelis, G.; Millar, S.E. Towards a molecular understanding of hair loss and its treatment. Trends Mol. Med. 2001, 7, 293-301. [CrossRef]

40. Stough, D.; Stenn, K.; Haber, R.; Parsley, W.M.; Vogel, J.E.; Whiting, D.A.; Washenik, K. Psychological effect, pathophysiology, and management of androgenetic alopecia in men. Mayo Clin. Proc. 2005, 80, 1316-1322. [CrossRef]

41. Lee, H.J.; Lee, S.H. Epidermal permeability barrier defects and barrier repair therapy in atopic dermatitis. Allergy Asthma Immunol. Res. 2014, 6, 276-287. [CrossRef] [PubMed]

42. Leung, D.Y. Atopic dermatitis: New insights and opportunities for therapeutic intervention. J. Allergy Clin. Immunol. 2000, 105, 860-876. [CrossRef] [PubMed]

43. Friedman, E.S.; LaNatra, N.; Stiller, M.J. Nsaids in dermatologic therapy: Review and preview. J. Cutan. Med. Surg. 2002, 6, 449-459. [CrossRef] [PubMed]

44. Belvisi, M.G.; Hele, D.J. Soft steroids: A new approach to the treatment of inflammatory airways diseases. Pulm. Pharmacol. Ther. 2003, 16, 321-325. [CrossRef] 
45. Simons, F.E. The antiallergic effects of antihistamines (h1-receptor antagonists). J. Allergy Clin. Immunol. 1992, 90, 705-715. [CrossRef]

46. Schafer-Korting, M.; Schmid, M.H.; Korting, H.C. Topical glucocorticoids with improved risk-benefit ratio. Rationale of a new concept. Drug Saf. 1996, 14, 375-385. [CrossRef] [PubMed]

47. Kim, K.H.; Lee, W.R.; An, H.J.; Kim, J.Y.; Chung, H.; Han, S.M.; Lee, M.L.; Lee, K.G.; Pak, S.C.; Park, K.K. Bee venom ameliorates compound 48/80-induced atopic dermatitis-related symptoms. Int. J. Clin. Exp. Pathol. 2013, 6, 2896-2903. [PubMed]

48. Wakao, S.; Kuroda, Y.; Ogura, F.; Shigemoto, T.; Dezawa, M. Regenerative effects of mesenchymal stem cells: Contribution of muse cells, a novel pluripotent stem cell type that resides in mesenchymal cells. Cells 2012, 1, 1045-1060. [CrossRef]

49. You, C.E.; Moon, S.H.; Lee, K.H.; Kim, K.H.; Park, C.W.; Seo, S.J.; Cho, S.H. Effects of emollient containing bee venom on atopic dermatitis: A double-blinded, randomized, base-controlled, multicenter study of 136 patients. Ann. Dermatol. 2016, 28, 593-599. [CrossRef]

50. Gu, H.; Kim, W.H.; An, H.J.; Kim, J.Y.; Gwon, M.G.; Han, S.M.; Leem, J.; Park, K.K. Therapeutic effects of bee venom on experimental atopic dermatitis. Mol. Med. Rep. 2018, 18, 3711-3718. [CrossRef]

51. Kim, Y.; Lee, Y.-W.; Kim, H.; Chung, D.K. Bee venom alleviates atopic dermatitis symptoms through the upregulation of decay-accelerating factor (daf/cd55). Toxins 2019, 11, 239. [CrossRef]

52. Leung, D.Y.; Hanifin, J.M.; Charlesworth, E.N.; Li, J.T.; Bernstein, I.L.; Berger, W.E.; Blessing-Moore, J.; Fineman, S.; Lee, F.E.; Nicklas, R.A.; et al. Disease management of atopic dermatitis: A practice parameter. Ann. Allergy Asthma Immunol. 1997, 79, 197-211.

53. Sur, B.; Lee, B.; Yeom, M.; Hong, J.H.; Kwon, S.; Kim, S.T.; Lee, H.S.; Park, H.J.; Lee, H.; Hahm, D.H. Bee venom acupuncture alleviates trimellitic anhydride-induced atopic dermatitis-like skin lesions in mice. BMC Complement. Altern. Med. 2016, 16, 38. [CrossRef]

54. An, H.J.; Kim, J.Y.; Kim, W.H.; Gwon, M.G.; Gu, H.M.; Jeon, M.J.; Han, S.M.; Pak, S.C.; Lee, C.K.; Park, I.S.; et al. Therapeutic effects of bee venom and its major component, melittin, on atopic dermatitis in vivo and in vitro. Br. J. Pharmacol. 2018, 175, 4310-4324. [CrossRef]

55. Kim, W.H.; An, H.J.; Kim, J.Y.; Gwon, M.G.; Gu, H.; Jeon, M.; Sung, W.J.; Han, S.M.; Pak, S.C.; Kim, M.K.; et al. Beneficial effects of melittin on ovalbumin-induced atopic dermatitis in mouse. Sci. Rep. 2017, 7, 17679. [CrossRef]

56. Dennis, E.A.; Rhee, S.G.; Billah, M.M.; Hannun, Y.A. Role of phospholipase in generating lipid second messengers in signal transduction. FASEB J. 1991, 5, 2068-2077. [CrossRef]

57. Mukherjee, A.B.; Miele, L.; Pattabiraman, N. Phospholipase $A_{2}$ enzymes: Regulation and physiological role. Biochem. Pharmacol. 1994, 48, 1-10. [CrossRef]

58. Jung, K.H.; Baek, H.; Kang, M.; Kim, N.; Lee, S.Y.; Bae, H. Bee venom phospholipase a2 ameliorates house dust mite extract induced atopic dermatitis like skin lesions in mice. Toxins 2017, 9, 68. [CrossRef]

59. Amano, W.; Nakajima, S.; Kunugi, H.; Numata, Y.; Kitoh, A.; Egawa, G.; Dainichi, T.; Honda, T.; Otsuka, A.; Kimoto, Y.; et al. The janus kinase inhibitor jte-052 improves skin barrier function through suppressing signal transducer and activator of transcription 3 signaling. J. Allergy Clin. Immunol. 2015, 136, 667-677. [CrossRef]

60. Tu, W.C.; Wu, C.C.; Hsieh, H.L.; Chen, C.Y.; Hsu, S.L. Honeybee venom induces calcium-dependent but caspase-independent apoptotic cell death in human melanoma a2058 cells. Toxicon 2008, 52, 318-329. [CrossRef]

61. Soman, N.R.; Baldwin, S.L.; Hu, G.; Marsh, J.N.; Lanza, G.M.; Heuser, J.E.; Arbeit, J.M.; Wickline, S.A.; Schlesinger, P.H. Molecularly targeted nanocarriers deliver the cytolytic peptide melittin specifically to tumor cells in mice, reducing tumor growth. J. Clin. Investig. 2009, 119, 2830-2842. [CrossRef]

62. Shai, Y. Mechanism of the binding, insertion and destabilization of phospholipid bilayer membranes by alpha-helical antimicrobial and cell non-selective membrane-lytic peptides. Biochim. Biophys. Acta 1999, 1462, 55-70. [CrossRef]

63. Fett, N.M. Morphea (localized scleroderma). JAMA Dermatol. 2013, 149, 1124. [CrossRef]

64. Hwang, J.H.; Kim, K.H. Bee venom acupuncture for circumscribed morphea in a patient with systemic sclerosis: A case report. Medicine 2018, 97, e13404. [CrossRef]

65. Jones, S.A.; McArdle, F.; Jack, C.I.; Jackson, M.J. Effect of antioxidant supplementation on the adaptive response of human skin fibroblasts to uv-induced oxidative stress. Redox Rep. 1999, 4, 291-299. [CrossRef] 
66. Katiyar, S.K.; Bergamo, B.M.; Vyalil, P.K.; Elmets, C.A. Green tea polyphenols: DNA photodamage and photoimmunology. J. Photochem. Photobiol. B 2001, 65, 109-114. [CrossRef]

67. Han, S.; Lee, K.; Yeo, J.; Kweon, H.; Woo, S.; Lee, M.; Baek, H.; Park, K. Inhibitory effect of bee venom against ultraviolet $\mathrm{b}$ induced mmp-11 and mmp-3 in human dermal fibroblasts. J. Apic. Res. 2007, 46, 94-98. [CrossRef]

68. Lee, H.; Bae, S.K.; Pyo, M.; Heo, Y.; Kim, C.G.; Kang, C.; Kim, E. Anti-wrinkle effect of pla2-free bee venom against uvb-irradiated human skin cells. J. Agric. Life Sci. 2015, 49, 125-135.

69. Makrantonaki, E.; Zouboulis, C.C. Molecular mechanisms of skin aging: State of the art. Ann. N. Y. Acad. Sci. 2007, 1119, 40-50. [CrossRef]

70. Schon, M.P.; Boehncke, W.H. Psoriasis. N. Engl. J. Med. 2005, 352, 1899-1912. [CrossRef]

71. Hegazi, A.G.; Raboh, F.A.A.; Ramzy, N.E.; Shaaban, D.M.; Khader, D.Y. Bee venom and propolis as new treatment modality in patients with localized plaque psoriases. Int. Res. J. Med. Med. Sci. 2013, 1, 27-33.

72. Mizutani, H.; Ohmoto, Y.; Mizutani, T.; Murata, M.; Shimizu, M. Role of increased production of monocytes TNF- $\alpha$, IL- $1 \beta$ and IL- 6 in psoriasis: Relation to focal infection, disease activity and responses to treatments. J. Dermatol. Sci. 1997, 14, 145-153. [CrossRef]

73. Feldman, S. Advances in psoriasis treatment. Dermatol. Online J. 2000, 6, 4.

74. Williams, I.R.; Kupper, T.S. Immunity at the surface: Homeostatic mechanisms of the skin immune system. Life Sci. 1996, 58, 1485-1507. [CrossRef]

75. Eltaher, S.; Mohammed, G.F.; Younes, S.; Elakhras, A. Efficacy of the apitherapy in the treatment of recalcitrant localized plaque psoriasis and evaluation of tumor necrosis factor-alpha (tnf-alpha) serum level: A double-blind randomized clinical trial. J. Dermatol. Treat. 2015, 26, 335-339. [CrossRef]

76. Coenen, J. Late results of a triple-layer artificial skin. In Proceedings of the European Burn Association 5th Congres, Brighton, UK, 20-23 September 1993.

77. Rothe, M.; Falanga, V. Growth factors: Their biology and promise in dermatologic diseases and tissue repair. JAMA Dermatol. 1989, 125, 1390-1398. [CrossRef]

78. Singer, A.J.; Clark, R.A. Cutaneous wound healing. N. Engl. J. Med. 1999, 341, 738-746. [CrossRef]

79. Han, S.; Lee, K.; Yeo, J.; Kim, W.; Park, K. Biological effects of treatment of an animal skin wound with honeybee (apis mellifera. L) venom. J. Plast. Reconstr. Aesthet. Surg. 2011, 64, e67-e72. [CrossRef]

80. Galkowska, H.; Wojewodzka, U.; Olszewski, W.L. Chemokines, cytokines, and growth factors in keratinocytes and dermal endothelial cells in the margin of chronic diabetic foot ulcers. Wound Repair Regen 2006, 14, 558-565. [CrossRef]

81. Goren, I.; Muller, E.; Pfeilschifter, J.; Frank, S. Severely impaired insulin signaling in chronic wounds of diabetic ob/ob mice: A potential role of tumor necrosis factor-alpha. Am. J. Pathol. 2006, 168, 765-777. [CrossRef]

82. Hozzein, W.N.; Badr, G.; Badr, B.M.; Allam, A.; Ghamdi, A.A.; Al-Wadaan, M.A.; Al-Waili, N.S. Bee venom improves diabetic wound healing by protecting functional macrophages from apoptosis and enhancing nrf2, ang-1 and tie-2 signaling. Mol. Immunol. 2018, 103, 322-335. [CrossRef]

83. Han, S.M.; Lee, K.G.; Park, K.K.; Pak, S.C. Skin sensitization study of bee venom (Apis mellifera L.) in guinea pigs and rats. Cutan. Ocul. Toxicol. 2013, 32, 27-30. [CrossRef]

84. Han, S.M.; Hong, I.P.; Woo, S.O.; Chun, S.N.; Park, K.K.; Nicholls, Y.M.; Pak, S.C. The beneficial effects of honeybee-venom serum on facial wrinkles in humans. Clin. Interv. Aging 2015, 10, 1587-1592. [CrossRef]

85. Lan, C.C.; Chen, G.S.; Chiou, M.H.; Wu, C.S.; Chang, C.H.; Yu, H.S. Fk506 promotes melanocyte and melanoblast growth and creates a favourable milieu for cell migration via keratinocytes: Possible mechanisms of how tacrolimus ointment induces repigmentation in patients with vitiligo. Br. J. Dermatol. 2005, 153, 498-505. [CrossRef]

86. Scott, G.A.; Jacobs, S.E.; Pentland, A.P. Spla2-x stimulates cutaneous melanocyte dendricity and pigmentation through a lysophosphatidylcholine-dependent mechanism. J. Investig. Dermatol. 2006, 126, 855-861. [CrossRef]

87. Maeda, K.; Tomita, Y.; Naganuma, M.; Tagami, H. Phospholipases induce melanogenesis in organ-cultured skin. Photochem. Photobiol. 1996, 64, 220-223. [CrossRef]

88. Maeda, K.; Naganuma, M. Melanocyte-stimulating properties of secretory phospholipase $\mathrm{A}_{2}$. Photochem. Photobiol. 1997, 65, 145-149. [CrossRef] 
89. Jeon, S.; Kim, N.H.; Koo, B.S.; Lee, H.J.; Lee, A.Y. Bee venom stimulates human melanocyte proliferation, melanogenesis, dendricity and migration. Exp. Mol. Med. 2007, 39, 603-613. [CrossRef]

90. Chomnawang, M.T.; Surassmo, S.; Nukoolkarn, V.S.; Gritsanapan, W. Antimicrobial effects of thai medicinal plants against acne-inducing bacteria. J. Ethnopharmacol. 2005, 101, 330-333. [CrossRef]

91. Nakatsuji, T.; Kao, M.C.; Fang, J.Y.; Zouboulis, C.C.; Zhang, L.; Gallo, R.L.; Huang, C.M. Antimicrobial property of lauric acid against propionibacterium acnes: Its therapeutic potential for inflammatory acne vulgaris. J. Investig. Dermatol. 2009, 129, 2480-2488. [CrossRef]

92. Leyden, J.J.; Del Rosso, J.Q.; Webster, G.F. Clinical considerations in the treatment of acne vulgaris and other inflammatory skin disorders: A status report. Dermatol. Clin. 2009, 27, 1-15. [CrossRef] [PubMed]

93. Bojar, R.A.; Holland, K.T. Acne and propionibacterium acnes. Clin. Dermatol. 2004, 22, 375-379. [CrossRef] [PubMed]

94. Lebwohl, M.G.; Heymann, W.R.; Berth-Jones, J.; Coulson, I. Impetigo. In Treatment of Skin Disease E-Book: Comprehensive Therapeutic Strategies, 4th ed.; Elsevier Health Sciences: Amsterdam, The Netherlands, 2013; p. 332.

95. Lebwohl, M.G.; Heymann, W.R.; Berth-Jones, J.; Coulson, I. Paronychia. In Treatment of Skin Disease E-Book: Comprehensive Therapeutic Strategies, 4th ed.; Elsevier Health Sciences: Amsterdam, The Netherlands, 2013; p. 542.

96. Lebwohl, M.G.; Heymann, W.R.; Berth-Jones, J.; Coulson, I. Staphylococcal Scalded Skin Syndrome. In Treatment of Skin Disease E-Book: Comprehensive Therapeutic Strategies, 4th ed.; Elsevier Health Sciences: Amsterdam, The Netherlands, 2013; p. 723.

97. Taylor, A.R. Methicillin-resistant staphylococcus aureus infections. Prim. Care Clin. Off. Pract. 2013, 40, 637-654. [CrossRef] [PubMed]

98. Choi, J.H.; Jang, A.Y.; Lin, S.; Lim, S.; Kim, D.; Park, K.; Han, S.-M.; Yeo, J.-H.; Seo, H.S. Melittin, a honeybee venom-derived antimicrobial peptide, may target methicillin-resistant staphylococcus aureus. Mol. Med. Rep. 2015, 12, 6483-6490. [CrossRef] [PubMed]

99. Lebwohl, M.G.; Heymann, W.R.; Berth-Jones, J.; Coulson, I. Tinea Pedis and Skin Dermatophytosis. In Treatment of Skin Disease E-Book: Comprehensive Therapeutic Strategies, 4th ed.; Elsevier Health Sciences: Amsterdam, The Netherlands, 2013; p. 756.

100. Yu, A.R.; Kim, J.J.; Park, G.S.; Oh, S.M.; Han, C.S.; Lee, M.Y. Biochemistry: The antifungal activity of bee venom against dermatophytes. J. Appl. Biol. Chem. 2012, 55, 7-11. [CrossRef]

101. Park, J.; Kwon, O.; An, H.J.; Park, K.K. Antifungal effects of bee venom components on trichophyton rubrum: A novel approach of bee venom study for possible emerging antifungal agent. Ann. Dermatol. 2018, 30, 202-210. [CrossRef] [PubMed]

102. Lebwohl, M.G.; Heymann, W.R.; Berth-Jones, J.; Coulson, I. Cutaneous Candidiasis and Chronic Mucocutaneous Candidasis. In Treatment of Skin Disease E-Book: Comprehensive Therapeutic Strategies, 4th ed.; Elsevier Health Sciences: Amsterdam, The Netherlands, 2013; p. 157.

103. Lee, S.B. Antifungal activity of bee venom and sweet bee venom against clinically isolated candida albicans. J. Pharmacopunct. 2016, 19, 45-50. [CrossRef]

104. Park, C.; Lee, D.G. Melittin induces apoptotic features in candida albicans. Biochem. Biophys. Res. Commun. 2010, 394, 170-172. [CrossRef]

105. Prakash, S.; Bhargava, H. Apis cerana bee venom: It's antidiabetic and anti-dandruff activity against malassezia furfur. World Appl. Sci. J. 2014, 32, 343-348.

106. Lebwohl, M.G.; Heymann, W.R.; Berth-Jones, J.; Coulson, I. Herpes Labialis. In Treatment of Skin Disease E-Book: Comprehensive Therapeutic Strategies, 4th ed.; Elsevier Health Sciences: Amsterdam, The Netherlands, 2013; p. 308.

107. Kim, J.-Y.; Lee, W.-R.; Kim, K.-H.; An, H.-J.; Chang, Y.-C.; Han, S.-M.; Park, Y.-Y.; Pak, S.C.; Park, K.-K. Effects of bee venom against propionibacterium acnes-induced inflammation in human keratinocytes and monocytes. Int. J. Mol. Med. 2015, 35, 1651-1656. [CrossRef]

108. Park, J.H.; Yim, B.K.; Lee, J.H.; Lee, S.; Kim, T.H. Risk associated with bee venom therapy: A systematic review and meta-analysis. PLoS ONE 2015, 10, e0126971. [CrossRef] [PubMed] 
109. Cavallucci, E.; Ramondo, S.; Renzetti, A.; Turi, M.C.; Di Claudio, F.; Braga, M.; Incorvaia, C.; Schiavone, C.; Ballone, E.; Di Gioacchino, M. Maintenance venom immunotherapy administered at a 3-month interval preserves safety and efficacy and improves adherence. J. Investig. Allergol. Clin. Immunol. 2010, 20, $63-68$. [PubMed]

110. Kim, J.-H.; Kim, M.-S.; Lee, J.-Y.; Yeom, S.-R.; Kwon, Y.-D.; Kim, D.-W. The case report of anaphylaxis after treated with bee-venom acupuncture. J. Korean Med. Rehabil. 2015, 25, 175-182. [CrossRef]

111. Lee, S.-K.; Ye, Y.-M.; Park, H.-S.; Jang, G.C.; Jee, Y.-K.; Park, H.-K.; Koh, Y.-I.; Kim, J.-H.; Kim, C.-W.; Hur, G.-Y. Hymenoptera venom anaphylaxis in adult korean: A multicenter retrospective case study. Allergy Asthma Respir. Dis. 2014, 2, 344-351.

112. Alam, M.; Ratner, D. Cutaneous squamous-cell carcinoma. N. Engl. J. Med. 2001, 344, 975-983. [CrossRef] [PubMed]

113. Lomas, A.; Leonardi-Bee, J.; Bath-Hextall, F. A systematic review of worldwide incidence of nonmelanoma skin cancer. Br. J. Dermatol. 2012, 166, 1069-1080. [CrossRef]

114. Grossman, D.; Leffell, D.J. The molecular basis of nonmelanoma skin cancer: New understanding. Arch. Dermatol. 1997, 133, 1263-1270. [CrossRef]

115. Do, N.; Weindl, G.; Grohmann, L.; Salwiczek, M.; Koksch, B.; Korting, H.C.; Schafer-Korting, M. Cationic membrane-active peptides - anticancer and antifungal activity as well as penetration into human skin. Exp. Dermatol. 2014, 23, 326-331. [CrossRef]

(C) 2019 by the authors. Licensee MDPI, Basel, Switzerland. This article is an open access article distributed under the terms and conditions of the Creative Commons Attribution (CC BY) license (http://creativecommons.org/licenses/by/4.0/). 